\title{
Energetikoje naudojamų plienų senėjimo vertinimas pagal struktūros pokyčius
}

\section{Arūnas Baltušnikas,}

Irena Lukošiūtè,

Vidas Makarevičius,

Rita Kriūkienè,

Rimantas Levinskas,

Albertas Grybėnas

Lietuvos energetikos institutas, Medžiagų tyrimu ir bandymų laboratorija, Breslaujos g. 3, LT-44403 Kaunas El.paštas Arunas.Baltusnikas@lei.lt
Esant aukštai temperatūrai eksploatacijos metu plieno struktūra keičiasi. Struktūros pokyčiai sukelia stiprumo savybių blogèjimą ir greitina valkšnumo procesą, mažina plienų atsparumą nuovargiui.

Šiame straipsnyje apibendrinti karštyje stiprių plienų senèjimo aukštoje temperatūroje tyrimai. Mažai legiruoto perlitinio $12 \mathrm{X} 1 \mathrm{M} \Phi$ ir legiruoto feritinio-martensitinio $9 \mathrm{Cr} 1 \mathrm{MoVNb}$ (P91) plieno bandiniai buvo sendinami 600,650 ir $700{ }^{\circ} \mathrm{C}$ temperatūrose. Kokybinei ir kiekybinei struktūros pokyčių analizei metale esantys intermetaliniai junginiai buvo elektrochemiškai atskirti iš kietojo tirpalo ir jų kristalografinių parametrų ypatumai tirti rentgeno struktūrinès analizès metodu (XRD). Nustačius, kad šiuose plienuose vyraujantis karbidas $\mathrm{M}_{23} \mathrm{C}_{6}$ yra stabilus, o kristalinès gardelès parametro $a$ vertè nuolat dideja, buvo pasiūlyta ji naudoti kaip trukmès ir temperatūros indikatorių plienų pokyčiams įvertinti. Karbido $\mathrm{M}_{23} \mathrm{C}_{6}$ kristalinès gardelès parametro $a$ tikslioms vertèms apskaičiuoti buvo naudojamos kompiuterinès programos (Powder Cell, GSAS ir Topas 4.2), pagrịstos Le Bail ir Rietveld algoritmais. Karbido $\mathrm{M}_{23} \mathrm{C}_{6}$ kristalinès gardelès parametro $a$ pokyčio kinetika sendinimo metu aprašyta taikant Johnson-Mehl-Avrami (JMA) dèsni. Ivertinta plienų gardelès transformacijos aktyvacijos energija $E$, transformacijos greičio konstanta $k$ ir Avrami komponente $n$. Šie skaičiavimai leido sudaryti plienų 12X1MФ ir P91 struktūrinių parametrų pokyčių trukmès ir temperatūros priklausomumus, kurie gali būti naudojami šių plienų darbiniam būviui ịvertinti.

Raktažodžiai: karštyje stiprus plienas, senejjimas, karbidai, XRD analizè, JMA dèsnis

\section{IVADAS}

Daugelyje šalių dar veikia senesnès kartos elektrinès, kuriose garo gamybos ir transportavimo įrengimai yra pagaminti iš mažai legiruoto (iki 2,5\% legiravimo elementų), mažaanglio $(0,08 \leq \mathrm{C} \leq 0,3 \%)$ plieno. Šiame pliene pagrin- diniai legiravimo elementai yra chromas (Cr), molibdenas (Mo) ir vanadis $(\mathrm{V})$, suteikiantys plienams ne tik atsparumą korozijai ir oksidacijai, bet ir esant aukštai temperatūrai mechaninį stiprumą. Europos Sąjungoje naudojami $0,5 \mathrm{Cr} 0,5 \mathrm{Mo} 0,25 \mathrm{~V}$ ir 2,25Cr1Mo markių plienai [1-3]. Šių plienų cheminè sudètis nulemia jų 
darbinius parametrus - temperatūrą iki $565{ }^{\circ} \mathrm{C}$ ir garo slègi iki $30 \mathrm{MPa}$. Lietuvos elektrinèse eksploatuojami $1,2 \mathrm{Cr} 0,3 \mathrm{Mo} 0,3 \mathrm{~V} \quad(12 \mathrm{X} 1 \mathrm{M} \Phi)$, $1,5 \mathrm{Cr} 1 \mathrm{Mo} 0,4 \mathrm{~V}(15 \mathrm{X} 1 \mathrm{M} 1 \Phi)$ ir $1,5 \mathrm{Cr} 1 \mathrm{Mo} 0,4 \mathrm{VL}$ (15X1М1ФЛ) markiu plienai $500-560{ }^{\circ} \mathrm{C}$ temperatūroje ir esant $10-15 \mathrm{MPa}$ garo slègiui [4]. Naujos kartos šiluminių elektrinių bei atominių reaktorių saugai, svarbių sistemų gamybai tiek JAV, tiek Europos šalyse plačiau taikomi karštyje stiprūs feritiniai-martensitiniai, turintys 9-12\% $\mathrm{Cr}$ - P91 (9Cr1MoVNb), P92 (9Cr0,5Mo1.8WV$\mathrm{Nb}), \mathrm{X} 12 \mathrm{CrMoWVNbN}$ ir kt., plienai.

Šiuolaikiniai energetiniai įrenginiai dèl aukštesnès temperatūros, didesnių slègių, agresyvesnès darbo aplinkos poveikio medžiagoms, numatomo ilgesnio eksploatacinio resurso ir kitų veiksnių visumos iškèlè papildomus reikalavimus medžiagoms, jų ilgaamžiškumui bei patikimumui. Todèl tyrimai šioje srityje, prognozuojant naujų energetinių irrenginių eksploatacijos laiką ar sprendžiant veikiančių darbo resurso pratęsimo uždavinius, siekiant nustatyti plienų patikimas patvarumo ribas, yra aktualūs. Atsižvelgiant ị naujus medžiagoms keliamus reikalavimus, esamų duomenų, taikytų ịvairių šalių projektavimo normuc metodikose (PCC-MRx, R5, ASME-NH, DDS ir kt.), šiuo metu nepakanka visiškai apibūdinti naujos kartos plienus. Šiems uždaviniams spręsti inicijuojami tarptautiniai projektai, pavyzdžiui, 7-osios bendrosios programos „MATTER“, programos „Horizontas 2020“ „INCEFA+“ ir kt.

Medžiagos parinkimą vamzdynams, ịrenginių korpusinèms detalèms bei kitiems konstrukciniams elementams lemia darbo aplinka ir eksploatacijos parametrai. Ilgalaikès eksploatacijos metu, esant aukštoms temperatūroms, plieno struktūra keičiasi $[5,6]$. Struktūros pokyčiai daro įtaką stiprumo savybių blogejjimui ir greitina valkšnumo procesą [5, 7-9]. Todèl ilgalaikès eksploatacijos metu struktūros degradacija, veikiant darbinèms apkrovoms, gali tapti pagrindiniu veiksniu, sukeliančiu irimo procesą. Atlikti tyrimai, taikant ịvairius analizès metodus, patvirtina tiesioginị mikrostruktūros būklès ir atsparumo valkšnumui priklausomumą [1, $3,10-18]$.

Esant aukštai temperatūrai, eksploatacijos metu plienuose išsiskiria karbidai, nitridai ir kt., kurių struktūra sudaryta iš ìvairių cheminių elementų, naudojamų plieno legiravimui, norint suteikti lydiniui tam tikras savybes. Vieni elementai stabdo išsiskyrusių junginių, didinančių plieno atsparumą valkšnumui, tirpumą arba slopina nenaudingų ir net žalingų junginių susidarymą. Kiti elementai ilgiau palaiko kietojo tirpalo pastovumą, užtikrinantị lydinio atsparumą korozijai [2].

Ivairūs tyrimai parodè, kad net nedidelis kiekis karbidų, išsiskiriančių eksploatuojant karštyje stiprius plienus, turi didelès ittakos lydinio mechaninems, fizikinèms ir cheminèms savybèms.

Seka, pagal kurią pliene susidaro karbidai, priklauso nuo lydinio cheminès sudeties ir terminio apdirbimo. Intermetalidai (karbidai, nitridai) lemia plieno mikrostruktūrą, nuo kurios priklauso lydinio mechaninès savybès. Pirmasis karbidas, susidarantis pliene atleidimo metu, paprastai būna termodinamiškai nestabiliausias, tačiau ilgainiui formuojasi kiti, žymiai stabilesni, karbidai, kurių susidarymas paprastai vyksta pagal dèsningą seką [19].

D. Bakeris ir J. Nuttingas pirmieji išsamiai ištyrè karbidų susidarymo eigą 2,25Cr-1Mo pliene, esant temperatūroms nuo 400 iki $750{ }^{\circ} \mathrm{C}$ [20], o kiti tyrejjai įrodè, kad karbidų išsiskyrimo raida priklauso ir nuo plieno cheminès sudèties [21]. Kembridžo universiteto profesorius $\mathrm{H}$. Bhadeshia su kolegomis tyrè karbidų susidarymo seką mažai legiruotuose šiluminių elektrinių plienuose [21]. Tirtiesiems plienams jie sudare trukmès-temperatūros-karbidų sudèties (TTT) fazines diagramas. Šia tema paskelbta daug kitu tyrimų, susijusių su ịvairių legiravimo elementų difuzija ir fazinès sudèties pokyčiais įvairiuose plienuose. Paskelbti darbai rodo, kad, skiriantis plienų cheminei sudèčiai, analogiškų fazinių virsmų kinetika gali keistis, o nuo to priklauso lydinių savybès.

Šiuo metu daug žinoma apie plienuose išsiskiriančių junginių sudètị, struktūrą, morfologiją ir kristalų išsidèstymo orientaciją. Pagrindiniai mažai legiruotame ir mažai anglies turinčiame karštyje stipriame $12 \mathrm{X} 1 \mathrm{M} \Phi$ pliene išsiskiriantys junginiai yra $\mathrm{Fe}_{3} \mathrm{C}, \mathrm{MC}, \mathrm{M}_{7} \mathrm{C}_{3}$ ir $\mathrm{M}_{23} \mathrm{C}_{6}$ karbidai [22], o P91 pliene $-\mathrm{M}_{23} \mathrm{C}_{6}$, NbN ir MX karbidai ir karbonitridai [23]. Eksploatuojant 12X1M plieną, cementito $\left(\mathrm{Fe}_{3} \mathrm{C}\right)$ grūdeliai tirpsta ir transformuojasi $\mathfrak{i}$ termodinamiškai stabilius bei vyraujančius, ilgai aukštoje temperatūroje 
išlaikytame pliene, legiruotuosius karbidus $\mathrm{M}_{7} \mathrm{C}_{3}$ ir $\mathrm{M}_{23} \mathrm{C}_{6}$, o eksploatuojant feritinius-martensitinius plienus, turinčius $9-12 \% \mathrm{Cr}$, pradiniai karbidai netirpsta, bet susidaro naujos fazès (Laves ir Z) [24-26]. Vienas svarbiausių plieno būsenos ìvertinimo rodiklių yra karbidų fazinè sudètis, jų kiekis, koaguliacijos bei sferoidizacijos laipsnis, kristalinių gardelių parametrų pokyčiai.

Šiame straipsnyje buvo tiriami karštyje stiprūs plienai: mažai legiruotas 12X1MФ ir naujos kartos legiruotas 9Cr-1Mo (P91). Atlikti ilgalaikiai eksperimentiniai šių plienų senejjimo proceso tyrimai, nustatant bei modeliuojant struktūros pokyčiu dèsningumus veikiant trukmei ir temperatūrai. Tyrimai atlikti taikant rentgeno spinduliuotes difrakcinès analizės metodą, kuris sudaro galimybę kokybiškai ir kiekybiškai identifikuoti karbidus, karbonitridus, Laves, Z ir kt. fazes, taip pat nustatyti legiravimo elementų juose kitimą. Kadangi šiuo metodu plieno struktūroje sunku tiesiogiai nustatyti atskirus junginius / fazes, kurių kiekis plienuose dažniausiai yra artimas matavimo jautrumo ribai $(0,5-3,0 \%)$, buvo atlikti tyrimai ir sudaryta jų išskyrimo iš metalo matricos metodika.

\section{TYRIMŲ IRANGA IR METODAI}

Tirti energetikoje naudojami karštyje stiprūs plienai: perlitinis mažai legiruotas 12X1M $\Phi$ ir feritinis-martensitinis legiruotas P91. Plienų cheminè sudètis pateikta 1 lentelëje.

\section{Bandinių paruošimas ir izoterminis sendinimas}

Plieno bandiniai buvo sendinami elektrinèse krosnyse 600,650 ir $700{ }^{\circ} \mathrm{C}$ temperatūroje, jos pastovumą palaikant $\pm 1{ }^{\circ} \mathrm{C}$. Temperatūros palaikymo tikslumas buvo tikrinamas kalibruotomis termoporomis. Siekiant užtikrinti vienodą temperatūros pasiskirstymą bandiniuose bei sumažinti oksidaciją, bandiniai buvo patalpinti į plienines dèžutes ir užpilti ištisiniu kalcio karbonato sluoksniu. Tyrimams naudoti $18 \times 12 \times 30 \mathrm{~mm}$ bandiniai. Sendinimo trukmè ir laiko intervalas buvo koreguojami atsižvelgiant $\mathfrak{i}$ logaritmini vykstančių struktūrinių pokyčiu priklausomumą.

\section{Šviesos (optinė) mikroskopija ir skenuojanti elektroninè mikroskopija (SEM) su EDX}

Plieno bandinių paviršiaus mikrostruktūros ir morfologijos tyrimai atlikti naudojant optini mikroskopą Olympus BX51TF, skaitmeninę 21MPix kamerą QImaging, programinę i̇rangą QCapture Pro bei skenuojantį elektroninį mikroskopą ZEISS EVO MA10 (greitinančioji ittampa $20 \mathrm{kV}$ ) su EDX detektoriumi Bruker XFlash 6/10. Plieno 12X1MФ mikrostruktūrai išryškinti poliruota bandinio plokštuma 20-40 s ésdinta $5 \%$ nitalio tirpalu, o plieno P91 - Vilella reagentu, po to nuplauta vandeniu, etanoliu ir išdžiovinta karštu oru.

\section{XRD analize}

Plieno 12X1MФ karbidų XRD analizè atlikta bendros paskirties rentgeno difraktometru ДРОН-УМ1. Rentgeno spinduliuotès $\mathrm{CuK}_{\alpha}$ spektrui išskirti naudotas grafito monochromatorius (difrakcijos plokštuma $d_{(002)}=0,3352 \mathrm{~nm}$ ), kuris panaikina foną, atsirandantị dèl nekoherentinès rentgeno spinduliuotès sklaidos plyšiuose ir bandinio laikiklyje, bei fluorescencinę spinduliuotę. Tai ypač svarbu tiriant su $\mathrm{CuK}_{\alpha}$ spinduliuote geležies junginius. Difrakcinès kreivès užrašytos, detektoriui judant $1 \%$ greičiu, intensyvumą matuojant kas $0,02^{\circ}$. Legiruoto P91 atskirtų metalų karbidu XRD analizè atlikta naudojant rentgeno spindulių difraktometrą Bruker D8 Advance; 2,4 kW rentgeno spindulių vamzdị su $\mathrm{Cu}$ anodu, Bragg-Brentano optiką ir 1-D detektorių LynxEye su Ni-filtru. Goniometras suderintas naudojant $\mathrm{Al}_{2} \mathrm{O}_{3}$ standartą NIST 1976A Corundum.

Difrakcinès kreives užrašytos $25-100^{\circ} 2 \theta$ kampų intervale, užrašymo žingsnis $-0,02^{\circ}$, matavimo trukme žingsnyje - $40 \mathrm{~s}$. Plieno nemetaliniai cheminiai junginiai identifikuoti programa Diffrac.Eva [27] naudojant PDF2 kristalografinių duomenų bazę [28].

1 lentelè. Karštyje stiprių plienų cheminè sudètis, \%

\begin{tabular}{c|c|c|c|c|c|c|c|c|c|c|c|c|c}
\hline Plienas & $\mathbf{C}$ & $\mathrm{Si}$ & $\mathrm{Mn}$ & $\mathbf{P}$ & $\mathrm{S}$ & $\mathbf{N}$ & $\mathrm{Al}$ & $\mathrm{Cr}$ & $\mathrm{Mo}$ & $\mathrm{Cu}$ & $\mathrm{Nb}$ & $\mathrm{Ni}$ & $\mathbf{V}$ \\
\hline 12X1MФ & 0,14 & 0,34 & 0,67 & 0,02 & 0,027 & $<0,0025$ & 0,0087 & 1,220 & 0,27 & 0,12 & 0,005 & 0,12 & 0,27 \\
\hline P91 & 0,094 & 0,38 & 0,35 & 0,006 & $<0,0005$ & 0,035 & 0,012 & 8,78 & 0,96 & 0,07 & 0,08 & 0,16 & 0,18 \\
\hline
\end{tabular}


Užrašant difrakcinę kreivę, jos profilis gali pasislinkti nuo tikrosios padèties dèl matavimo metu atsirandančių atsitiktinių ar sisteminių paklaidų. Karbidų kristalinių gardelių parametrų matavimo tikslumui padidinti $\mathfrak{i}$ tiriamąji milteliu pavidalo bandini buvo įmaišomas vidinis standartas (90 masès \% : 10 masès \%), pagamintas iš silicio (99,9 \% grynumo) monokristalo, kurio kristalinès gardelès briaunos ilgis $a=0,543088 \mathrm{~nm}$ (PDF Nr. 27-1402) [28]. Ši vertè buvo naudojama karbidų eksperimentinių difrakcinių maksimumu padètims patikslinti, skaičiuojant $\mathrm{M}_{23} \mathrm{C}_{6}$ karbido kristalinès gardelès

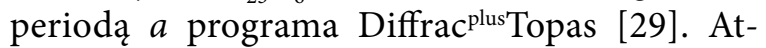
skirtų nuo metalo nuosèdu difrakciniam profiliui patikslinti ir periodui $a$ skaičiuoti buvo taikomas Le Bail metodas (1 pav.). Šis metodas ivertina kiekvieno cheminio junginio erdvinių grupių charakteristikas bei kristalinių gardelių parametrų vertes, jas patikslina ir teoriškai apskaičiuoja nuosėdų difrakcini profilį, geriausiai sutampantị su eksperimentiniu. Taikant Le Bail metodą, $\mathrm{M}_{23} \mathrm{C}_{6}$ karbido kristalinès gardelès briaunos $a$ vertè buvo išmatuota $\pm 0,00021 \AA$ tikslumu. Plieno atskirtų nuosèdų difrakcinių kreivių kiekybinei analizei taikytas Rietveld kristalinès struktūros patikslinimo metodas [29].

\section{Johnson-Mehl-Avrami dėsnio taikymas karbidų kiekio ir karbido $\mathrm{M}_{23} \mathrm{C}_{6}$ kristalinès gardelès parametro $a$ kitimui ịvertinti ir prognozuoti}

Karbidų $\mathrm{Fe}_{3} \mathrm{C}$ ir $\mathrm{M}_{23} \mathrm{C}_{6}$ santykinių kiekių pokyčiai, nustatyti matuojant difrakcinių maksimumų integralių intensyvumų vertes, ir karbido $\mathrm{M}_{23} \mathrm{C}_{6}$ kristalų gardelès parametro $a$ pokytis gali būti aprašyti Avrami kinetine lygtimi [31]:

$$
x(t)=1-\exp \left[-(k t)^{n}\right]
$$

čia: $x(t)$ - karbido kiekio arba parametro $a$ pokytis per laiką $t, k$ - karbido virsmo greičio konstanta, aprašoma lygtimi (2) ir yra susijusi su proceso aktyvacijos energija $E, n$ - virsmo eilè arba Avrami komponentė, aprašanti proceso, sužadinto veikiant temperatūrai, mechanizmą.

Temperatūros ịtaka virsmo greičiui (virsmo greitị ir temperatūrą sieja eksponentinis priklausomumas) aprašoma Arrhenius lygtimi [32]:

$$
k=A \cdot \exp \left(-{ }^{\mathrm{E}} /{ }_{\mathrm{RT}}\right)
$$

čia: $k$ - karbido virsmo greičio konstanta, $A$ - Arrhenius konstanta, apibūdinanti kiekvieną

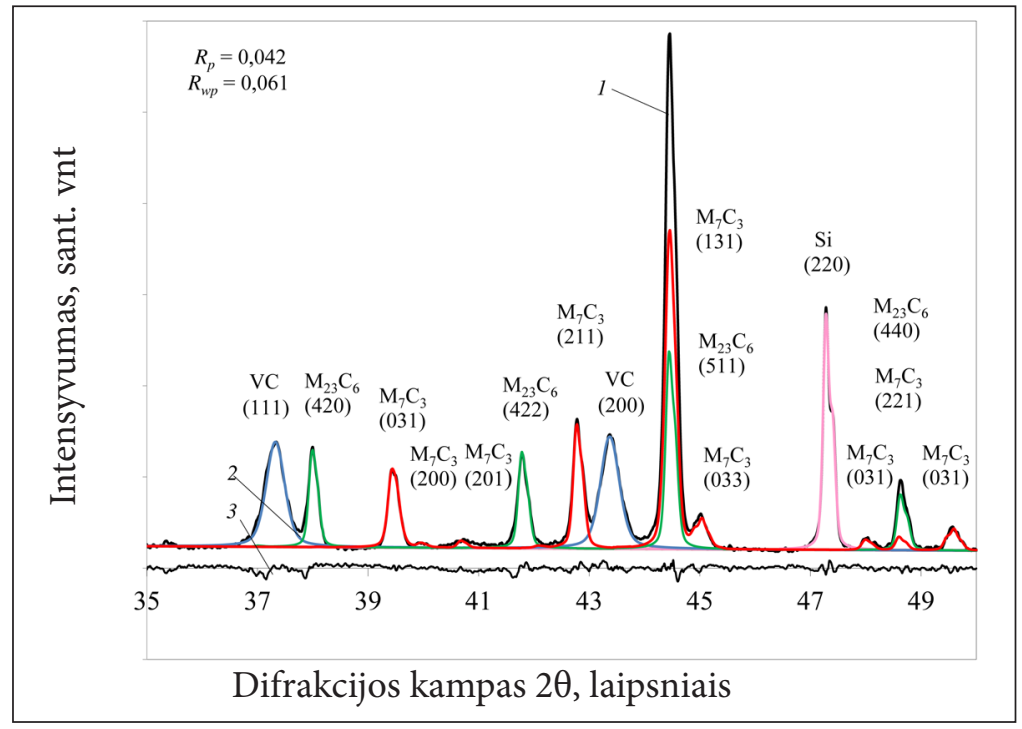

1 pav. Karbidų difrakcinio profilio analizės pavyzdys, taikant Le Bail profilių sulyginimo metodą. Difrakcinės kreivės: 1 - eksploatuoto 227000 val. plieno 12X1MФ atskirtų karbidų difraktograma, 2 - teorinis karbidų difrakcinis profilis, apskaičiuotas naudojant karbidų struktūrinius modelius ir atlikus difrakcinių maksimumų intensyvumų bei padèčių patikslinimą, 3 - skirtumas tarp teorinio ir eksperimentiškai užrašyto karbidų difrakcinių profilių [30] 
konkretų virsmą, $E$ - aktyvacijos energija, kJ/mol, $R$ - universalioji (molinė) dujų konstanta 8,314 J/ mol.K, $T$ - temperatūra kelvinais.

Norint apskaičiuoti $n$ ir $k$, Avrami lygtis išreiškiama logaritmine forma, kuri apjungia (1) ir (2) lygtis. Taip gaunamas Johnson-Mehl-Avrami (JMA) dèsnis, kuris aprašo karbido izoterminio virsmo kinetiką [33]:

$$
\ln (-\ln [1-x(t)])=n \ln k+n \ln t
$$

JMA dèsnis plačiai taikomas kietojo kūno fizikos ir chemijos, paviršiaus chemijos ir fizikos, metalurgijos, chemijos inžinerijos ir kitose medžiagų mokslo ir inžinerijos kryptyse, analizuojant virsmų (kristalizacija, kristalinių gardelių transformacija, vieno junginio virtimas kitu, kietojo tirpalo ir karbidų užuomazgų susidarymas, augimas ir sferoidizacija) kietoje medžiagos būsenoje izoterminèmis sąlygomis kinetiką [34, 35].

Taikant JMA dėsni, apskaičiuotos karbidų $\mathrm{Fe}_{3} \mathrm{C}$ ir $\mathrm{M}_{23} \mathrm{C}_{6}$ virsmų greičio ir virsmų eilès konstantos bei aktyvacijos energija [34]:

$$
E=R \cdot \frac{\left(\ln k_{1}-\ln k_{2}\right)}{1 / T_{2}-1 / T_{1}}, T_{1}>T_{2}
$$

čia: $k_{1}$ ir $k_{2}-$ virsmų, vykstančių $T_{1}$ ir $T_{2}$ temperatūrose, greičio konstantos.

Apskaičiavus aktyvacijos energiją, nustatoma karbido transformacijos greičio konstanta $k_{x}$ eksploatacinèje temperatūroje:

$$
\ln k_{x}=-\frac{E\left(1 / T_{x}-1 / T_{1}\right)}{R}+\ln k_{1}
$$

čia: $k_{x}$ - karbido virsmo, vykstančio eksploatacinejje temperatūroje, greičio konstanta; $T_{x}$ - eksploatacijos temperatūra kelvinais.

Karbidų kiekio (pagal difrakcinių maksimumų integralųji intensyvumą $I$ ) arba kristalinès gardelès parametro $a$ pokytis eksploatacineje temperatūroje apskaičiuojamas laisvai pasirenkant keletą eksploatacijos trukmès taškų:

$$
\ln \left[-\ln \frac{\left(I_{t}, a_{t}\right)}{I_{0}, a_{0}}\right]=f(\ln t) .
$$

\section{REZULTATAI IR JŲ APTARIMAS}

\section{Anodinè poliarizacija ir elektrocheminis èsdinimas: karbidų išskyrimas}

Rentgeno spinduliuotès difrakcinès analizès (XRD) metodu galima nustatyti karbidų susidarymo seką ir jų kristalinių gardelių pokyčius, atlikti karbidų, karbonitridų ar kitų cheminių junginių, pavyzdžiui, Laves fazių P91 pliene, pokyčių kokybinę bei kiekybinę analizę. Tačiau XRD metodo jautrumas yra nepakankamas, nes plienuose yra palyginti nedidelis kiekis karbidų. Norint analizuoti jų struktūrinius pokyčius taikant šį metodą, tiriamąsias fazes būtina išskirti iš plieno matricos. Todèl buvo atlikti tyrimai ir nustatyti optimalūs elektrocheminio èsdinimo parametrai.

Karbidų išskyrimas paremtas skirtingu jų atsparumu agresyviai aplinkai vykstant elektrocheminiams procesams, t. y. elektrocheminiu essdinimu, pagrịstu tiriamajji bandini sudarančių heterogeninių fazių nevienodu tirpimu elektrolitų tirpaluose, esant tam tikram potencialų skirtumui tarp bandinio ir netirpaus katodo (èsdinimas anodinio tirpinimo būdu). Kiekviena lydinị sudaranti fazè charakterizuojama tik jai vienai būdinga poliarizacijos kreive, o tos fazès tirpimo greitis priklauso nuo elektrolito sudèties, srovès tankio ir t. t. [36].

Naudojant potenciostatą PI-50-1 (maksimali darbinio elektrodo potencialo reguliavimo paklai$\mathrm{da} \pm 0,5 \mathrm{mV}$, srovès matavimo paklaida $\pm 0,2 \%$ ) ir programatorių PR-8 elektrolitų $20 \pm 2{ }^{\circ} \mathrm{C}$ tirpaluose užrašytos bandinių $(6 \times 0,2 \times 0,2 \mathrm{~cm}$, darbo plotas $2,2 \div 2,5 \mathrm{~cm}^{2}$ ) anodinès poliarizacijos kreivès. Bandinio potencialas nuo stacionarios vertès iki $1,2 \mathrm{~V}$ kito $5 \cdot 10^{-3} \mathrm{~V} / \mathrm{s}$ greičiu, o srovè matuota pagal sidabro chlorido lyginamajj elektrodą (EVL-1M3,1) [37].

Nustatant efektyvius tiriamojo plieno elektrocheminio èsdinimo tirpalus, užrašytos bandinių anodinès poliarizacijos kreivès keliuose elektrolitų tirpaluose (kalio chlorido, citrinos ir oksalo rūgščių, azoto ir druskos rūgščių). Ištyrus poliarizacijos kreives, nustatyti elektrocheminiai parametrai: stacionarusis ir kritinis potencialas, kritinis srovés tankis (apibūdina plieno potencialo ir stovès tankio, iki kurių dar vyrauja plieno tirpimas, ribas) [37]. 
Nustatyta, kad perlitini 12X1M $\Phi$ ir martensitinį P91 plieną tinkamiausia elektrochemiškai èsdinti $0,05 \%$ druskos ir $0,5 \%$ citrinos rūgšties tirpaluose. 2 a pav. ( 2 ir 3 kreives) pateiktos $12 \mathrm{X} 1 \mathrm{M} \Phi$ anodinès poliarizacijos kreivès rodo, kad elektrocheminio proceso metu bandinys nepasidengia pasyvinančiąja plèvele. Tuo tarpu oksalo rūgšties tirpale (2a pav., 1 kreivè) anodinis plieno tirpimas vyksta labai siaurose potencialu ribose (po to susiformuoja pasyvinančioji danga), todèl būtų sunku išlaikyti tokias sąlygas. Padidinus citrinos rūgšties koncentraciją nuo 0,5 iki $2 \%$, pasiekiamas $81,8 \mathrm{~mA} / \mathrm{cm}^{2}$ kritinis srovès tankis (2b pav., 3 kreive). Šiuo atveju, didejant bandinio potencialui, plieno paviršiuje pradeda formuotis pasyvinančioji plèvelè [37].

Atsižvelgiant $\mathfrak{i}$ eksperimentų rezultatus, elektrocheminiam plieno bandinių èsdinimui pasirinktas druskos rūgšties tirpalas, nes nustatyta, kad, didinant druskos rūgšties koncentraciją ir anodinès srovès tanki, tirtieji 12X1MФ ir P91
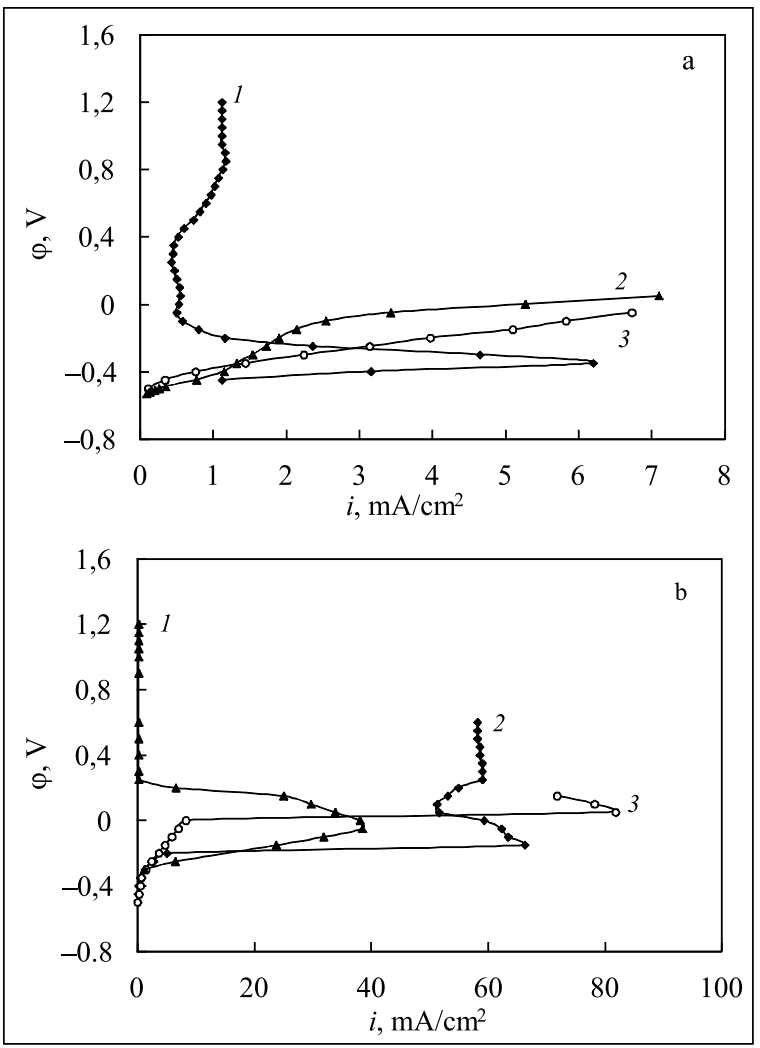

2 pav. Plieno $12 \times 1 \mathrm{M} \Phi$ anodinès poliarizacijos kreivès elektrolitų tirpaluose: $1 \mathrm{a}-0,5 \%$ oksalo r., $1 \mathrm{~b}-0,5 \%$ azoto r., $2 \mathrm{a}-0,05 \%$ druskos r., $2 \mathrm{~b}-0,5 \%$ kalio chlorido, $3 \mathrm{a}-0,5 \%$ citrinos r., $3 \mathrm{~b}-2 \%$ citrinos r. [37] plienai elektrolito tirpale nepasiekia kritinio srovès tankio (bandinys nepasidengia pasyvinančiąja plèvele ir elektrocheminio èsdinimo metu nuolat tirpsta). Nustatyti elektrocheminio ésdinimo parametrai, t. y. kritinis srovès tankis, kritinis potencialas, elektrolitas ir jo koncentracija. Tolesniuose eksperimentuose plienų bandiniai $(20 \times 10 \times 10 \mathrm{~mm}) 8$ val. ésdinti $5 \%$ druskos rūgšties vandeniniame tirpale naudojant nuolatinès srovès maitinimo šaltini 1621A BP Precision (voltmetro ir ampermetro matavimo paklaida $\pm 1 \%$ ) ir esant $130-150 \mathrm{~mA} / \mathrm{cm}^{2}$ srovès tankiui. Gauti tyrimų duomenys parodè, kad taikant šj metodą plieno $\mathrm{P} 91$ atveju, be $\mathrm{M}_{23} \mathrm{C}_{6}$ karbidų, yra išskiriami karbonitridai bei Laves fazès, kurios susidaro pliene jo senèjimo metu.

Indo dugne nusèdę karbidų ar kitų fazių milteliai išplauti distiliuotame vandenyje, išdžiovinti $95^{\circ} \mathrm{C}$ temperatūroje.

\section{Mikrostruktūros tyrimas ir karbidų sekos nustatymas}

Plienas 12X1MФ. Eksploatuoto ir sendinto laboratorinemis sąlygomis plieno mikrostruktūra pateikta 3 ir 4 pav.

Neeksploatuoto plieno optinès mikroskopijos nuotraukose stebimi perlito ir ferito grūdeliai, tačiau sunku identifikuoti smulkius karbidu darinius (3a pav.). Pakaitinus bandini 1080 val. $650{ }^{\circ} \mathrm{C}$, suyra perlito grūdeliai, susidaro legiruotieji karbidai, išsidèstę grūdeliuose ir jų ribose (3b pav.).

Pastebèta, kad, ilginant bandinių termino sendinimo trukmę ir keliant temperatūrą iki $700^{\circ} \mathrm{C}$, legiruotujų karbidų koncentracija grūdelių viduje ir ribose dideja, karbidai koaguliuoja, formuodami stambius grūdus ar grandinèles (3c pav.). Eksploatuoto plieno SEM nuotraukoje (4a pav.) stebima visiškai suirusio perlito struktūra, kurioje išsidèstę smulkūs karbidai bei ryškiai aplink grūdelius matomos koaguliavusių karbidų grandinèlès. Pasendinus bandinį 240 val. $650^{\circ} \mathrm{C}$ temperatūroje ( $4 \mathrm{~b}$ pav.) pastebima iš dalies suirusi feritinè-perlitiné plieno struktūra ir aiškiai matomos grūdelių ribose besiformuojančios karbidų grandinèlès, o po 2400 val. - matomas karbidu išsidèstymas ir grūdelių viduje (4c pav.).

Siekiant nustatyti struktūrinius kriterijus plienų 12X1MФ ir P91 būklei vertinti ir likusiam tarnavimo laikui prognozuoti, pirmiausia ištirta plienuose 


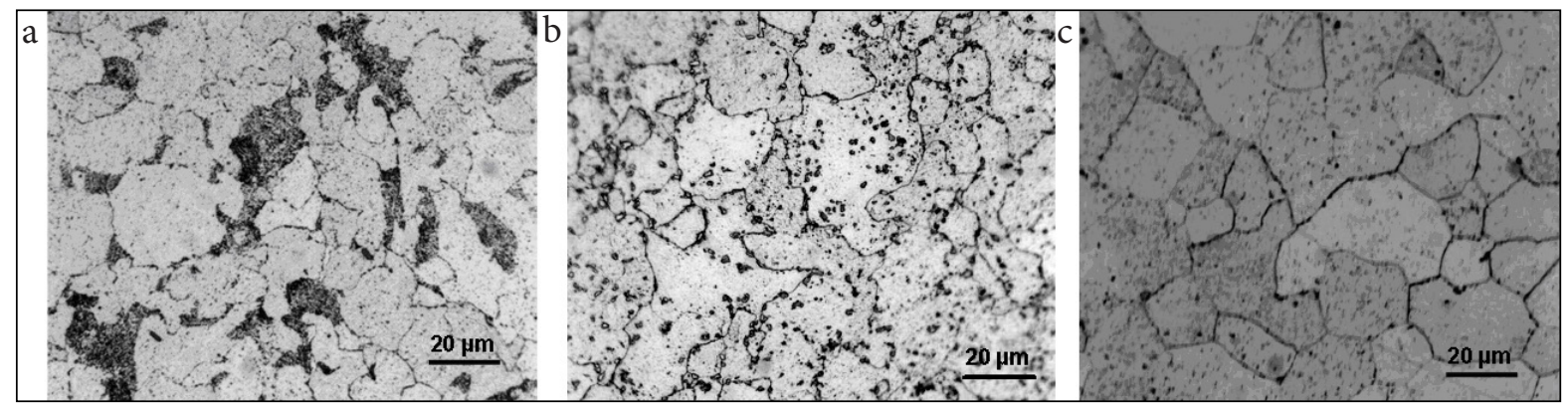

3 pav. Plieno 12X1MФ bandinių optinés mikroskopijos nuotraukos: a - pradinis, $b$ - sendintas 1080 val. $650^{\circ} \mathrm{C}, \mathrm{C}-2400$ val. $700{ }^{\circ} \mathrm{C}[30]$
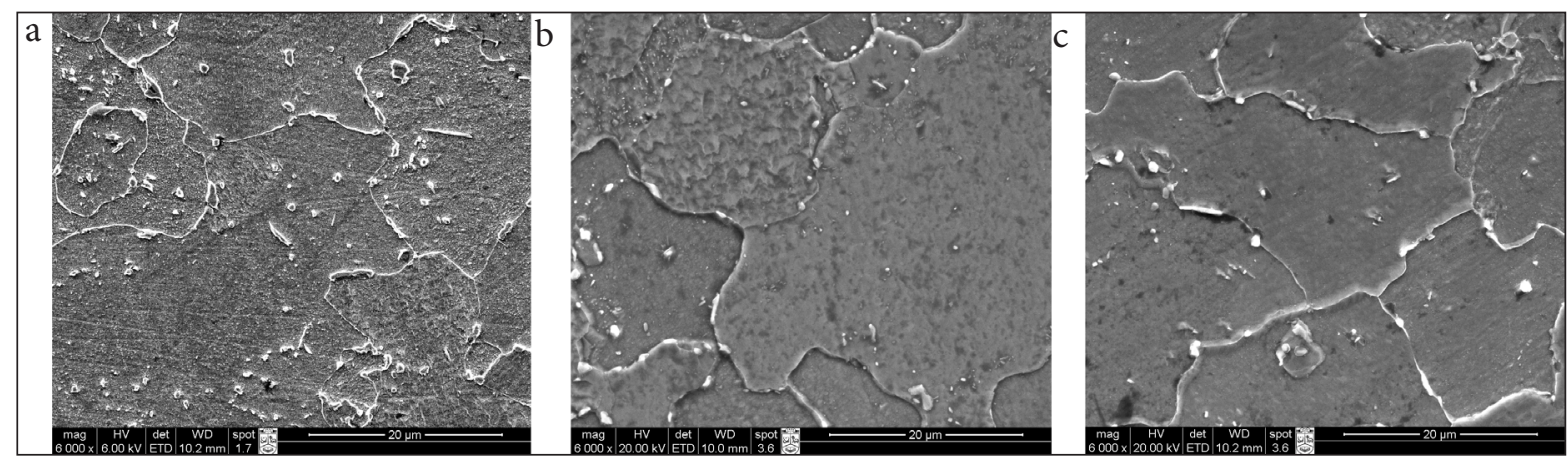

4 pav. Plieno 12X1MФ bandinių SEM nuotraukos (didinimas $6000^{\circ}$ ): a -227000 val. eksploatuotų $550^{\circ} \mathrm{C}$ temperatūroje esant $14 \mathrm{MPa}$ slègiui, b -240 val. ir c -2400 val. kaitintų $650^{\circ} \mathrm{C}$ temperatūroje [38]

susidarančių karbidų seka atsižvelgiant ị temperatūros intensyvumą ir sendinimo trukmę.

Apibendrinus tyrimų rezultatus nustatyta, kad sendinant 12X1M $\Phi$ plieną visose trijose temperatūrose $\left(600,650\right.$ ir $\left.700^{\circ} \mathrm{C}\right)$ vyksta panašūs karbidų pokyčiai, tik skirtingais greičiais. Karbidų susidarymo seka yra tokia:

$$
\begin{gathered}
\mathrm{M}_{3} \mathrm{C}+\mathrm{MC} \rightarrow \mathrm{M}_{3} \mathrm{C}+\mathrm{MC}+\mathrm{M}_{23} \mathrm{C}_{6} \rightarrow \mathrm{M}_{3} \mathrm{C}+\mathrm{M} \\
\mathrm{C}+\mathrm{M}_{23} \mathrm{C}_{6}+\mathrm{M}_{7} \mathrm{C}_{3} \rightarrow \mathrm{MC}+\mathrm{M}_{23} \mathrm{C}_{6}+\mathrm{M}_{7} \mathrm{C}_{3} .
\end{gathered}
$$

Svarbu pažymėti, kad nustatyta seka sutampa su eksploatuoto plieno bandiniuose susidarančia karbidų seka [20]. Tai leidžia teigti, kad laboratorinemis sąlygomis sendinto plieno 12X1MФ karbidų virsmų rentgeno struktūriniai tyrimo būdai yra korektiški ir gali būti naudingi sudarant eksploatuojamo plieno darbinès būsenos įvertinimo ir likusio tarnavimo laiko prognozès metodologiją. Ivvertinus susidariusių karbidų stabilumą sendinant plieną nustatyta, kad MC kiekis išlieka pastovus, $\mathrm{M}_{7} \mathrm{C}_{3}$ susiformuoja tik sendinimo proceso pabaigoje, o $\mathrm{M}_{3} \mathrm{C}$ ir $\mathrm{M}_{23} \mathrm{C}_{6}$ kiekis plieno bandiniuose tyrimo metu nuolat kinta [39], todèl pastarieji du karbidai pasirinkti tolesniems tyrimams.

Plienas P91. Pradinio ir sendinto laboratorinėmis sąlygomis plieno P91 mikrostruktūra pateikta 5 pav.

$\mathrm{M}_{23} \mathrm{C}_{6}$ karbidai išsidèstę aplink pirminio austenito grūdelius ir martensito plokštelių pakraščiuose, o smulkūs MX karbonitridai matomi grūdelių viduje (5a, b pav.). Plienuose, kuriuose anglies yra daugiau kaip $0,05 \%, \mathrm{M}_{23} \mathrm{C}_{6}$ karbidai vyrauja grūdelių ribose [40]. Pradiniame pliene $\mathrm{M}_{23} \mathrm{C}_{6}$ karbidų dydis siekia 150-200 nm, o plieną sendinant vidutinis dalelių skersmuo padidejja iki $1 \mu \mathrm{m}$ ir daugiau (5c, d pav.).

P91 plienas turi chromu prisotintą $\mathrm{M}_{23} \mathrm{C}_{6}$ karbidą ir vanadžiu arba niobiu prisotintus $\mathrm{M}(\mathrm{C}, \mathrm{N})$ karbidus / karbonitridus. Rietveld struktūros patikslinimo metodu nustatyta, kad $88,8 \%$ sudaro $\mathrm{M}_{23} \mathrm{C}_{6}$ karbidas, o MX struktūros vanadžiu ir niobiu prisotintų karbonitridų kiekis siekia atitinkamai 8,85 ir 2,35\% [40]. Šiluminio poveikio metu karbidai ir karbonitridai išlieka, bet keičiasi jų elementinè sudètis, o ilgainiui išsiskiria intermetalidas - Laves faze $\mathrm{Fe}_{2} \mathrm{Mo}$. Sendinant 650 ir $700^{\circ} \mathrm{C}$ temperatūrose 


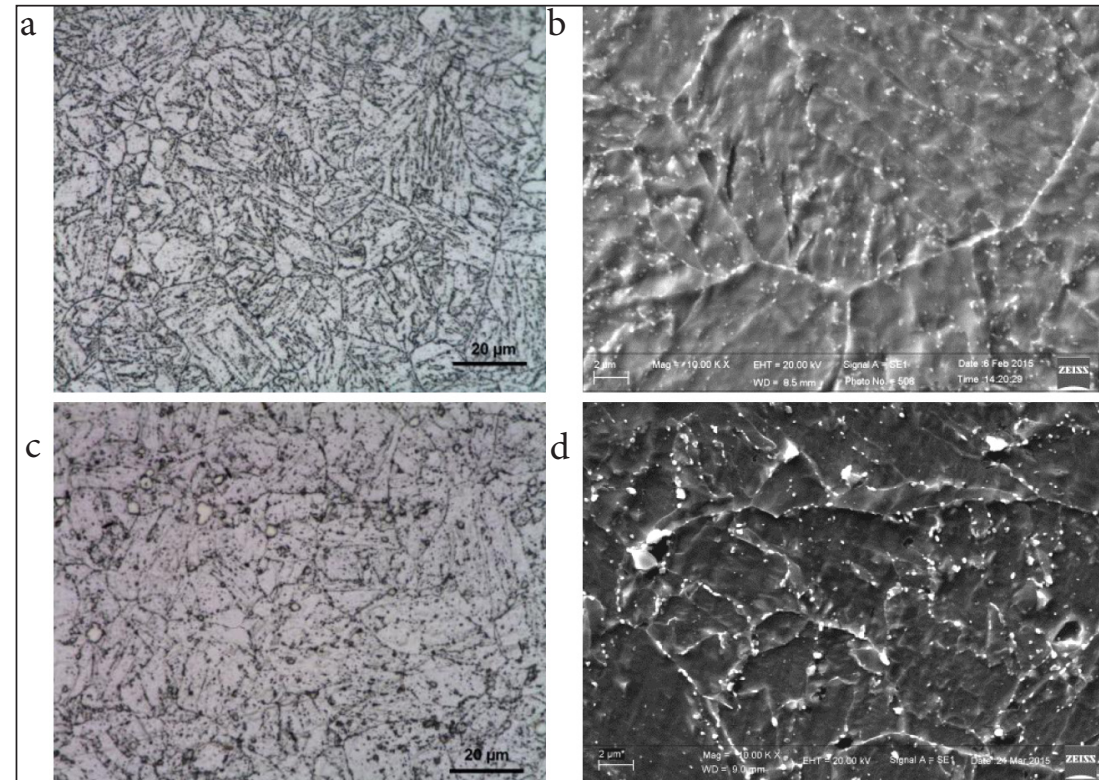

5 pav. Plieno P91 bandinių optinès mikroskopijos $(a, c)$ ir SEM (b, d; didinimas $10000^{x}$ ) nuotraukos: a, b - pradinis, c, d - sendintas 5640 val. $700^{\circ} \mathrm{C}$

Laves fazès XRD metodu neaptiktos. İsiskverbimo fazių sekas galima užrašyti:

$\mathrm{M}_{23} \mathrm{C}_{6}+\mathrm{V}(\mathrm{C}, \mathrm{N})+\mathrm{Nb}(\mathrm{C}, \mathrm{N}) \rightarrow \mathrm{M}_{23} \mathrm{C}_{6}+\mathrm{V}(\mathrm{C}, \mathrm{N})+$ $\mathrm{Nb}(\mathrm{C}, \mathrm{N})+\mathrm{Fe}_{2} \mathrm{Mo} ; 600^{\circ} \mathrm{C}$;

$\mathrm{M}_{23} \mathrm{C}_{6}+\mathrm{V}(\mathrm{C}, \mathrm{N})+\mathrm{Nb}(\mathrm{C}, \mathrm{N}) \rightarrow \mathrm{M}_{23} \mathrm{C}_{6}+\mathrm{V}(\mathrm{C}, \mathrm{N})+$ $\mathrm{Nb}(\mathrm{C}, \mathrm{N}) ; 650^{\circ} \mathrm{C}$;

$\mathrm{M}_{23} \mathrm{C}_{6}+\mathrm{V}(\mathrm{C}, \mathrm{N})+\mathrm{Nb}(\mathrm{C}, \mathrm{N}) \rightarrow \mathrm{M}_{23} \mathrm{C}_{6}+\mathrm{V}(\mathrm{C}, \mathrm{N})+$ $\mathrm{Nb}(\mathrm{C}, \mathrm{N}) ; 700^{\circ} \mathrm{C}[41]$.

\section{Karbidų kiekio nustatymas pagal XRD kreivių} maksimumų intensyvumą: struktūrinio senèjimo proceso kriterijaus parinkimas

Nustatytas 12X1MФ plieno sendinimo metu susidarančių $\mathrm{M}_{23} \mathrm{C}_{6}$ ir $\mathrm{M}_{3} \mathrm{C}$ karbidų kiekio priklauso- mumas nuo sendinimo temperatūros ir trukmès. Tuo tikslu buvo apskaičiuoti karbidų difrakcinių maksimumų, atitinkamai (422) ir (031), integralūs intensyvumai ir nustatyti jų priklausomumai nuo sendinimo trukmès (6 pav.) [39].

Karbidų santykinių kiekių vertès, apskaičiuotos pagal difrakcinių maksimumų (031) cementitui $\mathrm{Fe}_{3} \mathrm{C}$ ir (422) karbidui $\mathrm{M}_{23} \mathrm{C}_{6}$ integralujji intensyvumą (7 pav.), buvo pritaikytos karbidu pokyčiams modeliuoti izoterminèmis sąlygomis, taikant klasikini JMA dėsnį (3 lygtis). Taikant 4 lygti apskaičiuota proceso aktyvacijos energija, o 5 lygti - nustatyti karbidų integralūs intensyvumai plieną eksploatuojant $550{ }^{\circ} \mathrm{C}$ temperatūroje.

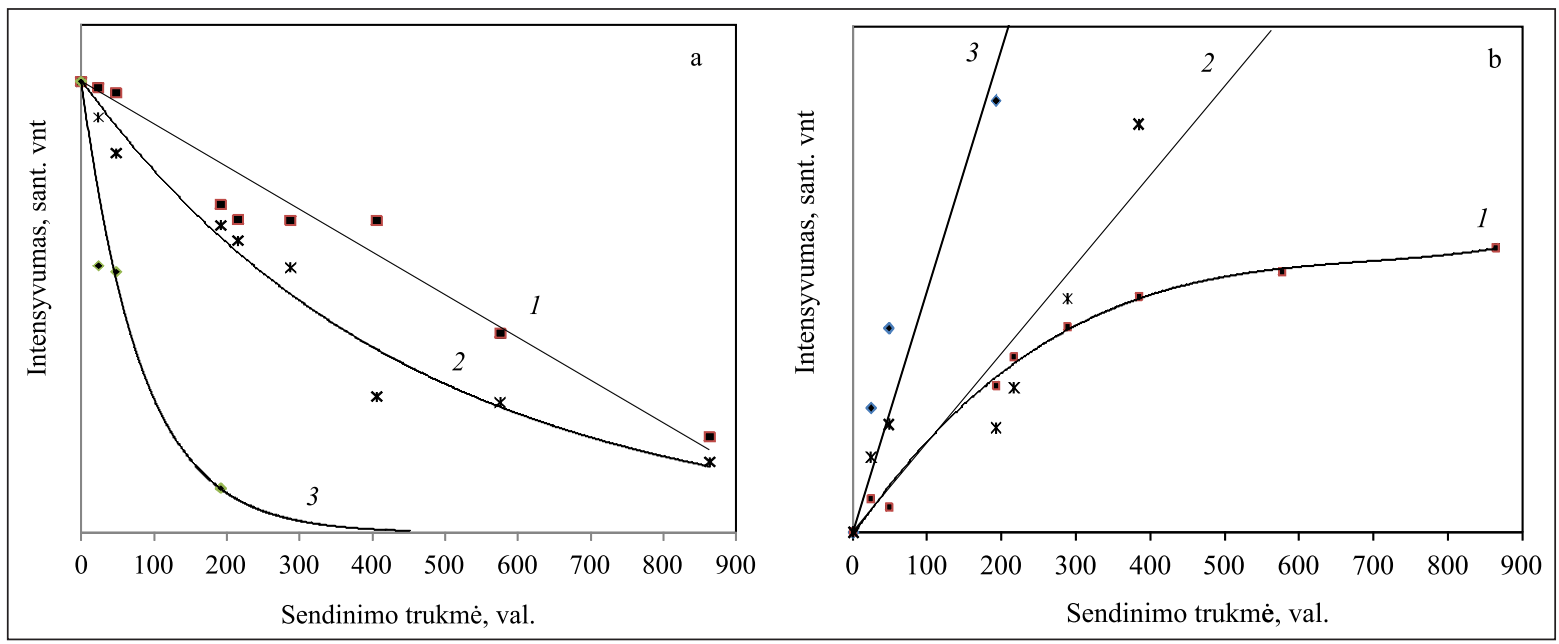

6 pav. Karbidų $\mathrm{Fe}_{3} \mathrm{C}(\mathrm{a})$ ir $\mathrm{M}_{23} \mathrm{C}_{6}$ (b) kiekio priklausomumas nuo plieno $12 \mathrm{X} 1 \mathrm{M} \Phi$ sendinimo temperatūros ir trukmès: $1-600^{\circ} \mathrm{C}, 2-650^{\circ} \mathrm{C}$, $3-700^{\circ} \mathrm{C}[39]$ 


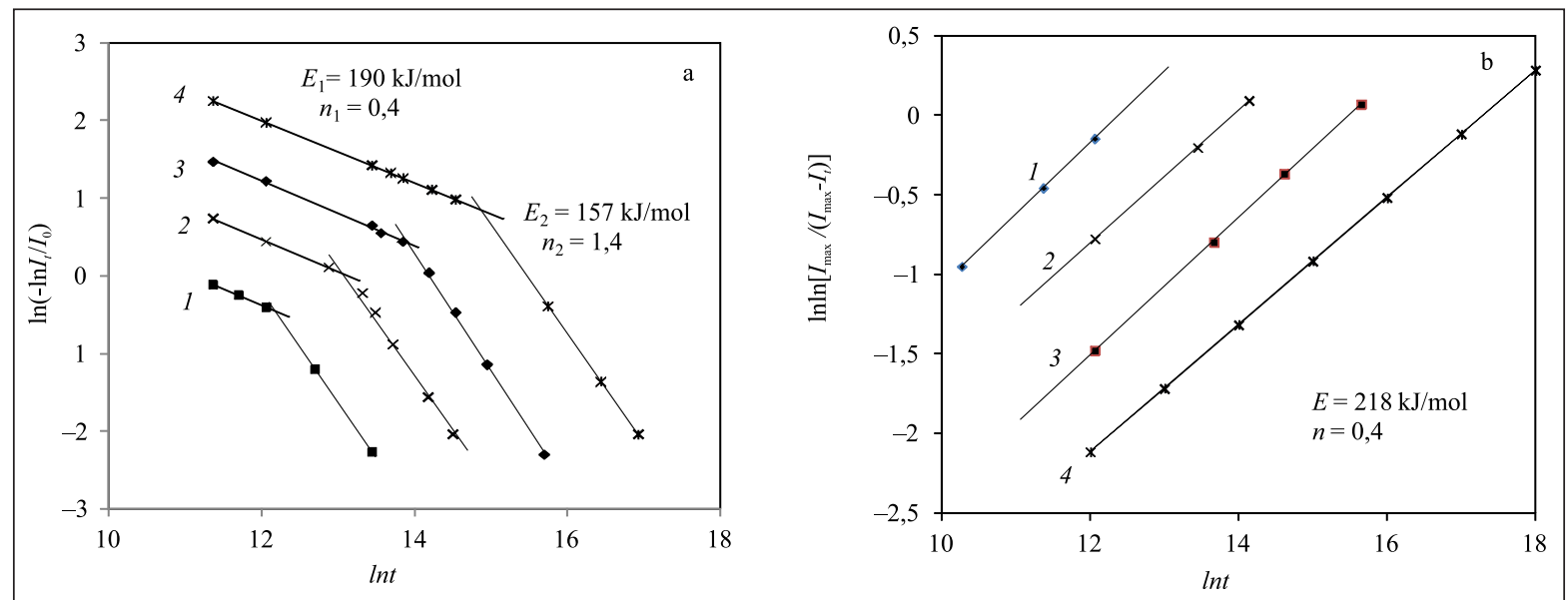

7 pav. Plieno 12X1MФ, izotermiškai sendinto skirtingose temperatūrose, karbidų $\mathrm{Fe}_{3} \mathrm{C}(\mathrm{a})$ ir $\mathrm{M}_{23} \mathrm{C}_{6}$ (b) kiekio pokyčio priklausomumas nuo sendinimo trukmès natūrinių logaritmų skalèse. Sendinimo temperatūros: $1-700^{\circ} \mathrm{C}, 2-650^{\circ} \mathrm{C}, 3-600^{\circ} \mathrm{C}$ ir $4-$ karbidų kiekio pokytis apskaičiuotas [42]

Karbido $\mathrm{Fe}_{3} \mathrm{C}$ kiekio pokyčio priklausomumas nuo laiko sudarytas iš dviejų nuosekliai einančių tiesių. Paaiškèjo, kad šio karbido virsmas vyksta dviem etapais, kurių kiekvienas aprašomas virsmų eile $n_{1}$ ir $n_{2}$ bei greičių konstantomis $k_{1}$ ir $k_{2}$. Taip pat apskaičiuotos šių dviejų stadijų aktyvacijos energijos $(E)-190$ ir $157 \mathrm{~kJ} / \mathrm{mol}$. Pirmosios $E$ gali būti siejama su stambių $\mathrm{Fe}_{3} \mathrm{C}$ dalelių tirpimu, o antroji - su likusių smulkių, turinčių didesnị paviršiaus plotą, tirpimu. Parametras $k$ priklauso nuo temperatūros ir gali būti nustatytas iš izoterminès trukmè-intensyvumas kreivès (6a ir 6b pav., 1-3 kr.). Kuo aukštesnè temperatūra, tuo virsmo greitis yra didesnis (2 lentelè).

\section{2 lentelè. $\mathrm{Fe}_{3} \mathrm{Cir}_{23} \mathrm{C}_{6}$ virsmų reakcijos greičio konstantos [42]}

\begin{tabular}{c|ccc}
\hline Temperatūra, $^{\circ} \mathrm{C}$ & \multicolumn{2}{|c|}{$\mathrm{Fe}_{3} \mathbf{C}$} & $\mathbf{M}_{23} \mathbf{C}_{6}$ \\
\hline 600 & $0,33 \cdot 10^{-6}$ & $0,68 \cdot 10^{-6}$ & $0,19 \cdot 10^{-6}$ \\
\hline 650 & $1,0 \cdot 10^{-6}$ & $1,30 \cdot 10^{-6}$ & $0,90 \cdot 10^{-6}$ \\
\hline 700 & $15,0 \cdot 10^{-6}$ & $7,60 \cdot 10^{-6}$ & $4,15 \cdot 10^{-6}$ \\
\hline
\end{tabular}

Skirtingai nei $\mathrm{Fe}_{3} \mathrm{C}$, karbido $\mathrm{M}_{23} \mathrm{C}_{6}$ kiekio didejimas vyksta viena stadija, kuriai būdinga $218 \mathrm{~kJ} / \mathrm{mol}$ aktyvacijos energija. Abiem atvejais pagal teoriškai apskaičiuotas eksploatacinès temperatūros $\left(550{ }^{\circ} \mathrm{C}\right)$ kreives galima nustatyti plieno $12 \mathrm{X} 1 \mathrm{M} \Phi$ realų eksploatacijos laiką ir numatyti tolesnę jo struktūros kitimo eigą. Tačiau po 384 val. sendinimo $650{ }^{\circ} \mathrm{C}$ temperatūroje karbidų $\mathrm{M}_{23} \mathrm{C}_{6}$ ir $\mathrm{M}_{7} \mathrm{C}_{3}$ difrakcinių maksimumų intensyvumai nebekinta. Todèl karbidų integralaus intensyvumo pokyčio priklausomumas nuo šiluminio poveikio trukmès gali būti naudingas vertinant tik ribotą laiką eksploatuoto plieno 12X1M $\Phi$ būklę. 12X1M $\Phi$ plieno eksploatacijos ar senèjimo metu karbidas $\mathrm{M}_{3} \mathrm{C}$ palaipsniui transformuojasi ị karbidą $\mathrm{M}_{23} \mathrm{C}_{6}$ [39], kuris išlieka visą eksploatavimo laikotarpi, bet kinta šio karbido kristalinès gardelès parametras $a$ (briaunos ilgis), nes Fe atomus, vykstant legiruojančių elementų difuzijai iš matricos ị karbido grūdelius, pakeičia Cr ir Mo. Šių elementų atominis spindulys yra didesnis (atitinkamai 0,125 ir $0,135 \mathrm{~nm})$, negu Fe $(0,124 \mathrm{~nm})$, todèl karbido kristalinè gardelė palaipsniui plečiasi (8 pav.) $[16,43,44]$. Dèl šios priežasties tolesniems tyrimams naudojome karbido $\mathrm{M}_{23} \mathrm{C}_{6}$ gardelès parametro $a$ vertę, kaip indikatorių plieno struktūros degradacijos laipsniui ivertinti. 8 pav. parodyta plieno 12X1MФ atskirtų karbidų difrakcinių profilių išplèsta atkarpa, išryškinanti aukštos temperatūros ir jos trukmès ịtaką karbidų struktūros pokyčiams. Trys laisvai pasirinktos būdingos difrakcinès kreivès rodo karbido $\mathrm{M}_{23} \mathrm{C}_{6}$ difrakcinių maksimumų 420 ir 422 poslinki mažų difrakcijos kampų link. Panašiai slenka ir karbido $\mathrm{M}_{7} \mathrm{C}_{3}$ difrakciniai maksimumai 150 ir 112 . Difrakcijos kampų mažèjimas rodo, kad karbido kristalų gardeleje dideja atitinkamas atstumas tarp kristalografinių plokštumų. 


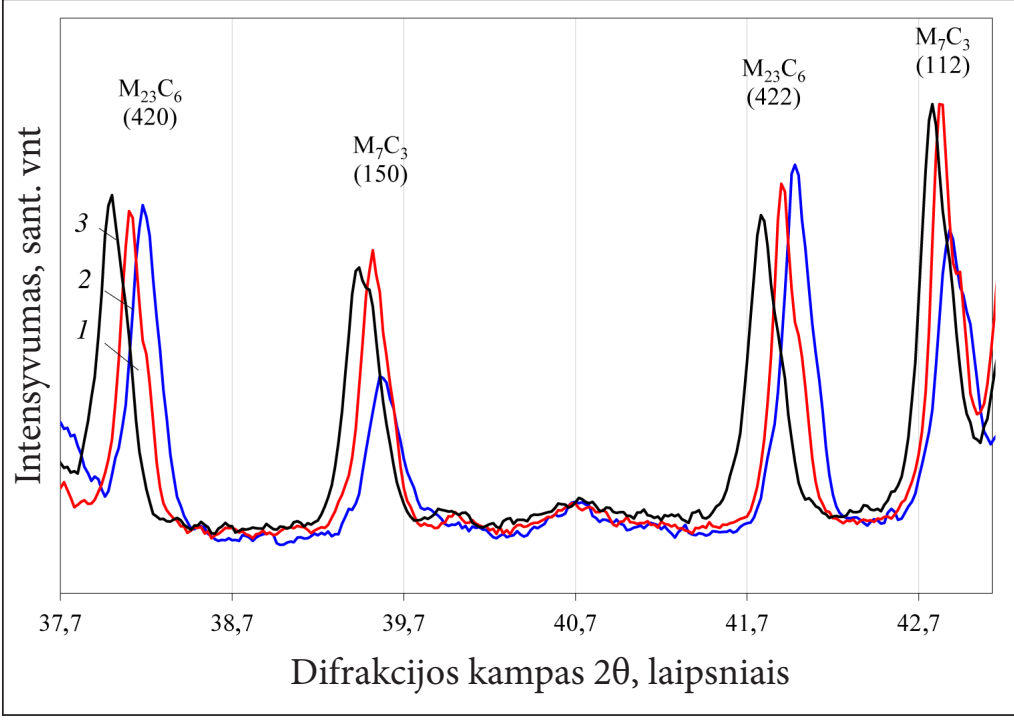

8 pav. Plieno $12 \times 1 \mathrm{M} Ф$ karbidų rentgeno spinduliuotés difrakcinès kreivès: 1 - plienas, sendintas $42 \mathrm{~h} 700{ }^{\circ} \mathrm{C}$ temperatūroje, 2 - plienas, sendintas $288 \mathrm{val}$. $700{ }^{\circ} \mathrm{C}$ temperatūroje ir 3 - plienas, eksploatuotas 227000 val. $550^{\circ} \mathrm{C}$ temperatūroje ir esant $14 \mathrm{MPa}$ slègiui [30]

\section{Karbido $\mathrm{M}_{23} \mathrm{C}_{6}$ kristalų gardelès parametro $a$ kitimo tyrimas}

Karbido $\mathrm{M}_{23} \mathrm{C}_{6}$ kristalinès gardelès parametro $a$ vertei apskaičiuoti naudota difrakcinių profilių analizès metodika - PowderCell programa ir Le Bail metodas.

Plienas 12X1MФ. Plieno 12X1MФ, sendinto 600,650 ir $700{ }^{\circ} \mathrm{C}$ temperatūrose, karbido kristalinès gardelès parametro $a$ pokyčio priklausomumas nuo sendinimo trukmés parodytas 9 pav. (atitinkamai 2-4 kr.). Taip pat buvo nustatytas ìvairų laiką eksploatuoto plieno karbido gardelès parametro $a$ pokytis (9 pav., $1 \mathrm{kr}$.) [30].

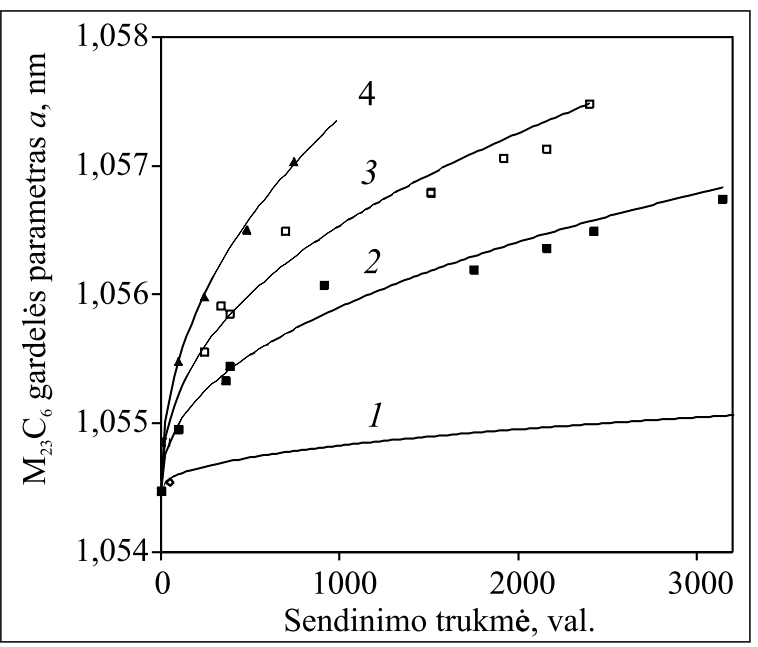

9 pav. Plieno $12 \times 1 \mathrm{M} \Phi$ karbido $\mathrm{M}_{23} \mathrm{C}_{6}$ kubinès kristalinès gardelès parametro a pokyčio priklausomumas nuo sendinimo trukmès. Kreivès: 1 - eksploatuotame pliene, 2 - sendintame $600{ }^{\circ} \mathrm{C}$, $3-650^{\circ} \mathrm{C}$ ir $4-700^{\circ} \mathrm{C}$ temperatūrose [30]
Plieno 12X1MФ parametro $a$ pokytis aprašytas JMA dèsniu (3 lygtis) ir pateiktas 10 pav.

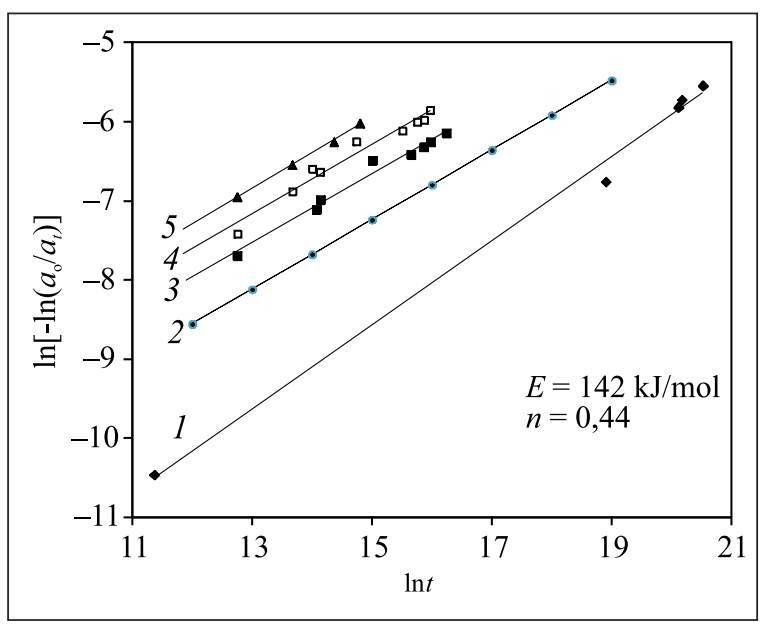

10 pav. Plieno 12X1MФ karbido $\mathrm{M}_{23} \mathrm{C}_{6}$ kristalo gardelès parametro a pokytis: 1 - eksploatuotame pliene, 2 - prognozuojamas parametro a pokytis $550^{\circ} \mathrm{C}$ temperatūroje, kai $n=0,44,3$ - sendintame $600^{\circ} \mathrm{C}$, $4-650^{\circ} \mathrm{C}$ ir $5-700^{\circ} \mathrm{C}$ temperatūrose [30]

Nustatyti tiesiniai priklausomumai (10 pav., 1 ir 3-5 kr.) rodo, kad legiravimo elementų difuzija aukštose temperatūrose vyksta pagal JMA dèsni. Proceso kinetiniai parametrai pateikti 3 lentelèje.

Taikant 4 lygtị apskaičiuota proceso, vykstančio $600-700{ }^{\circ} \mathrm{C}$ temperatūrų diapazone, aktyvacijos energija $E=142 \mathrm{~kJ} / \mathrm{mol}$ [30]. Karbido kristalinès gardelès transformacijos greičio konstanta $k_{x}$ apskaičiuota pagal 5 lygti eksploatacinei $550{ }^{\circ} \mathrm{C}$ temperatūrai, $k_{x}=2,17 \cdot 10^{-14}$. 
3 lentelè. Plieno 12X1MФ karbido $\mathrm{M}_{23} \mathrm{C}_{6}$ kristalų gardelès parametro a kitimo kinetiniai parametrai [30]

\begin{tabular}{c|c|c|c}
\hline $\boldsymbol{T},{ }^{\circ} \mathbf{C}$ & $\boldsymbol{n}$ & Ink & $\boldsymbol{k}$ \\
\hline 600 & 0,4368 & $-30,23$ & $7,24 \cdot 10^{-14}$ \\
\hline 650 & 0,4407 & $-29,28$ & $1,93 \cdot 10^{-13}$ \\
\hline 700 & 0,4497 & $-28,23$ & $5,51 \cdot 10^{-13}$ \\
\hline
\end{tabular}

Prognozuojamas parametro $a$ pokytis $550{ }^{\circ} \mathrm{C}$ temperatūroje, pateiktas 9 pav. $2 \mathrm{kr}$., išreiškiamas tiesès lygtimi:

$$
y=0,44 x-13,842
$$

čia: $y=\ln \left[-\ln \left(a_{0} / a_{t}\right)\right]$ ir $x=\ln t[30]$.

10 pav. 2 kreivè ir 7 lygtis gali būti naudojama plieno struktūros pokyčiams pagal karbido $\mathrm{M}_{23} \mathrm{C}_{6}$ kristalinès gardelès kitimus ịvertinti eksploatavimo temperatūroje arba žinant plieno eksploatavimo trukmę ir karbido $\mathrm{M}_{23} \mathrm{C}_{6}$ kristalinès gardelès parametro $a$ vertę galima apskaičiuoti vidutinę tikrąją šio plieno eksploatavimo temperatūrą. Be to, perrašius (3) lygti, galima prognozuoti parametro $a$ vertę bet kuriuo laiko $t$ momentu pasirinktinoje temperatūroje:

$$
a_{t}=\frac{a_{0}}{e^{-e^{(n \ln t+n \ln k)}}}
$$

čia: $a_{0}=1,05519 \mathrm{~nm}$ yra pradinio $12 \mathrm{X} 1 \mathrm{M} \Phi$ plieno $\mathrm{M}_{23} \mathrm{C}_{6}$ karbido kristalinés gardelès parametro verte, $n=0,44$ plieno $\mathrm{M}_{23} \mathrm{C}_{6}$ karbido kristalinès gardelès parametro a transformacijos Avrami komponentè.
Plienas P91. Pagrindinis intermetalinis junginys, susidarantis gaminant P91 plieną ir jam senejjant, yra $\mathrm{M}_{23} \mathrm{C}_{6}$ karbidas. Plieną eksploatuojant ar sendinant laboratorinèmis sąlygomis, kinta šio karbido kristalinès gardelès parametras $a$, nes vyksta legiravimo elementų difuzija iš matricos i karbido grūdelius. Todèl plieno P91 senejiimo kinetiką charakterizuojančiu struktūriniu parametru taip pat pasirinktas $\mathrm{M}_{23} \mathrm{C}_{6} \mathrm{ku}-$ binès kristalinès gardelès briaunos ilgio $a$ vertès pokytis. Kadangi $\mathrm{Cr}$ difuzijos koeficientas yra didesnis nei Mo, todèl ilgainiui, eksploatacijos ar sendinimo metu, karbido kristalineje gardeleje ima vyrauti $\mathrm{Cr}$ atomai [45].

EDX metodu nustatyta, kad $\mathrm{Cr} / \mathrm{Fe}$ masių santykis $\mathrm{M}_{23} \mathrm{C}_{6}$ karbido dalelèse priklauso nuo šiluminio sendinimo temperatūros ir trukmès. Keliant temperatūrą ir ilginant sendinimo trukmę, $\mathrm{Cr} / \mathrm{Fe}$ santykis dideja, taigi ir karbido kristalinès gardelès parametras auga.

Tikslūs $\mathrm{M}_{23} \mathrm{C}_{6}$ karbido kristalinès gardelès parametrai $a$ išmatuoti XRD metodu ir apskaičiuoti TOPAS 4.2 programa Le Bail metodu. Nustatyta, $\operatorname{kad} a$ vertès kinta nuo $1,06353 \mathrm{~nm}$ pradiniame pliene iki $1,06552 \mathrm{~nm}$ (3 168 val. sendintame $700{ }^{\circ} \mathrm{C}$ temperatūroje) ir iki $1,06595 \mathrm{~nm}$ (sendintame 9984 val. $650{ }^{\circ} \mathrm{C}$ temperatūroje).

Karbido $\mathrm{M}_{23} \mathrm{C}_{6}$ kristalinès gardelès parametro a priklausomumas nuo sendinimo temperatūros ir trukmès pateiktas 11 pav.

Karbido $\mathrm{M}_{23} \mathrm{C}_{6}$ parametro $a$ pokytis aprašytas JMA dèsniu (3 lygtis). Nustatyta, kad kristalinès gardelès parametras tam tikrame apibrèžtame

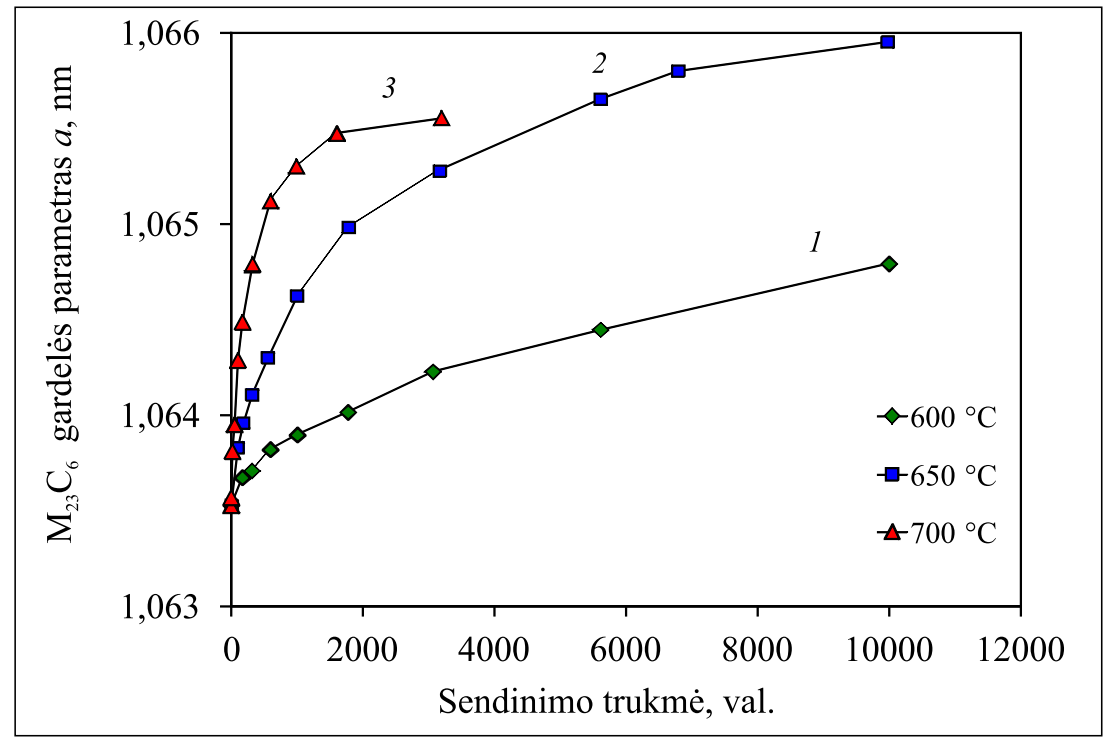

11 pav. $\mathrm{P} 91$ plieno $\mathrm{M}_{23} \mathrm{C}_{6}$ karbido kristalinés gardelès parametro $a$ priklausomumas nuo sendinimo temperatūros ir trukmès. Kreives: $1-600^{\circ} \mathrm{C}, 2-650^{\circ} \mathrm{C}, 3-700^{\circ} \mathrm{C}$ [40] 
plieno sendinimo trukmès intervale visose eksperimento temperatūrose $\left(600,650\right.$ ir $\left.700{ }^{\circ} \mathrm{C}\right)$ kinta tiesiškai. Tiesinio kitimo intervalo galiojimo sąlygos apibrèžtos 13 pav. grafike. Šiame intervale karbido $\mathrm{M}_{23} \mathrm{C}_{6}$ gardelès transformacijai galioja kinetinè Avrami lygtis (1 lygtis). Parametro $a$ transformaciją apibūdinančios krypties linijos aprašytos lygtimis:

$$
\begin{aligned}
& y_{\left(700{ }^{\circ} \mathrm{C}\right)}=0,541 x-14,249 ; \mathrm{R}^{2}=0,9981 ; \\
& y_{\left(650^{\circ} \mathrm{C}\right)}=0,5393 x-15,04 ; \mathrm{R}^{2}=0,9995 ; \\
& y_{\left(600{ }^{\circ} \mathrm{C}\right)}=0,5404 x-16,131 ; \mathrm{R}^{2}=0,9971 ;
\end{aligned}
$$

čia: $y=\ln \left[-\ln \left(a_{0} / a_{t}\right)\right]$, o $x=\ln t$.

Pagal eksperimento rezultatus tam tikroje temperatūroje aprašančių krypties linijų lygtis sudarytas bendras procesus apibūdinantis priklausomumas:

$$
\ln \left[-\ln \left(a_{d} / a_{t}\right)\right]_{T}=n \ln t-b_{T}
$$

čia: $b_{T}$ - krypties linijos susikirtimo su $y$ ašimi vertè.

Apskaičiuotos karbido $\mathrm{M}_{23} \mathrm{C}_{6}$ kristalinès gardelès parametro $a$ transformacijos greičio konstantos, kurių vertès priklauso nuo šiluminio sendinimo temperatūros - kuo aukštesnè temperatūra, tuo greičiau vyksta procesas. Parametro $n$ verte nepriklauso nuo plieno sendinimo temperatūros ir yra pastovus, kiekvienam plienui būdingas dydis, todèl tolesniuose skaičiavimuose buvo naudota jo vidutinè vertė $n=0,5402$. Taikant 10 lygti apskaičiuotas karbido kristalinès gardelès parametro a prognozuojamas kitimas eksploatacinejje temperatūroje:

$$
y_{\left(550^{\circ} \mathrm{C}\right)}=0,5402 x-17,247 .
$$

\section{Karbido $\mathrm{M}_{23} \mathrm{C}_{6}$ transformacijos aktyvacijos energijos skaičiavimas ir proceso kinetika} Pagal nustatytas karbido $\mathrm{M}_{23} \mathrm{C}_{6}$ transformacijos greičio konstantas buvo nubrèžtas jų verčių natūrinio logaritmo $(\ln k)$ priklausomumo nuo atvirkštinès sendinimo temperatūros $(1 / T)$ grafikas (Arrhenius grafikas) (12 pav.). Iš gautų tiesių nuolinkio verčių apskaičiuojama abiejų plienų karbido $\mathrm{M}_{23} \mathrm{C}_{6}$ transformacijos aktyvacijos energija.

Gardelès transformacijos aktyvacijos energija $E$ apskaičiuota pasinaudojus greičio konstantos $k$ priklausomumu nuo eksperimento temperatūros pagal 12 pav. parodytas tiesių lygtis plienui P91 ir 12X1M $\Phi[43]$ :

$$
E=-(\mathrm{C} \cdot 1000) R
$$

čia $\mathrm{C}=-29,8$ plienui $\mathrm{P} 91$ ir $\mathrm{C}=-17,1$ plienui $12 \mathrm{X} 1 \mathrm{M} \Phi, R=8,314 \mathrm{~J} / \mathrm{mol} \cdot \mathrm{K}$.

Palyginę dviejų plienų Arrhenius grafikus (12 pav.), matome, kad plieno $\mathrm{P} 91$ karbido $\mathrm{M}_{23} \mathrm{C}_{6}$ parametro $a$ kitimo aktyvacijos energijos $E$ vertè $248 \mathrm{~kJ} / \mathrm{mol}$ yra daug didesnè už 12X1MФ plieno parametro $a$ kitimo aktyvacijos energijos vertę, t. y. $E=142 \mathrm{~kJ} / \mathrm{mol}$ [30]. Iš gautų rezultatų matome,

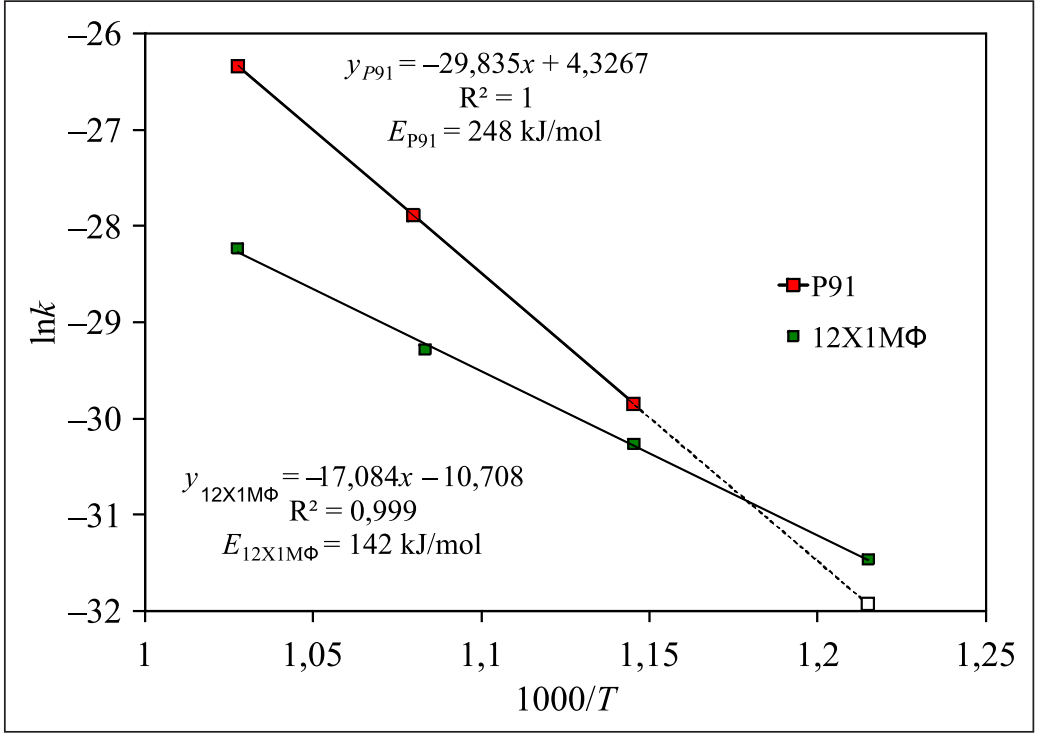

12 pav. Arrhenius grafikas, skirtas 12X1MФ ir P91 plienu $\mathrm{M}_{23} \mathrm{C}_{6}$ karbido transformaciijos aktyvacijos energijai nustatyti [40] 


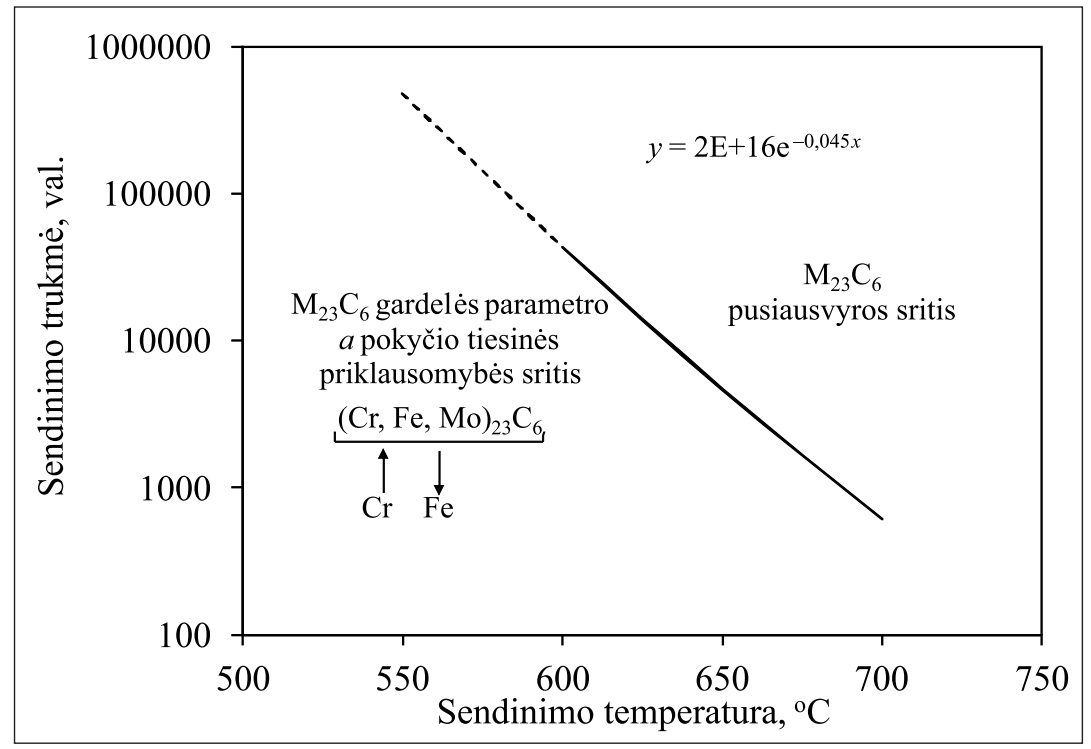

13 pav. JMA lygties galiojimo sąlygos tiesinei $\mathrm{M}_{23} \mathrm{C}_{6}$ karbido kristalinès gardelès parametro transformacijai [40]

kad vienodomis sąlygomis difuzijos procesai mažai legiruotame pliene $12 \mathrm{X} 1 \mathrm{M} \Phi$, taip pat ir jo senejjimas vyksta greičiau nei legiruoto $\mathrm{P} 91$ plieno.

Apskaičiuota P91 plieno $\mathrm{M}_{23} \mathrm{C}_{6}$ karbido kristalinès gardelès kitimo aktyvacijos energijos vertè yra artima chromo difuzijos feritineje matricoje $(267,7 \mathrm{~kJ} / \mathrm{mol})$ ir geležies difuzijos ferite $(250,6 \mathrm{~kJ} / \mathrm{mol})$ aktyvacijos energijoms, bet žymiai mažesnè už molibdeno difuzijos $\alpha$-Fe $E$ [46]. $\mathrm{Cr}$ difuzija, matyt, yra pagrindinis temperatūros sukeltas (aktyvuotas) procesas, nuo kurio priklauso $\mathrm{M}_{23} \mathrm{C}_{6}$ karbido formavimasis [40].

Pagal parametrą $a$ trijose temperatūrose aprašančias tiesių lygtis ir vidutinę $n$ vertę išvestas $\mathrm{M}_{23} \mathrm{C}_{6}$ karbido kristalinès gardelès $a$ pokyčius $550{ }^{\circ} \mathrm{C}$ temperatūroje apibūdinantis priklausomumas. Tyrimų rezultatai apibendrinti lygti$\mathrm{mi}$, analogiška plieno $12 \mathrm{X} 1 \mathrm{M} \Phi$ (8 lygtis), išreiškiančia $a$ vertès priklausomumą nuo sendinimo trukmès nustatytoje temperatūroje. Šioje lygtyje $a_{0}=1,06353 \mathrm{~nm}$ yra pradinio P91 plieno $\mathrm{M}_{23} \mathrm{C}_{6}$ karbido kristalinès gardelès parametro verté, $n=0,5402$ P91 plieno $\mathrm{M}_{23} \mathrm{C}_{6}$ karbido kristalinès gardelès parametro $a$ transformacijos Avrami komponentè.

Iš išraiškos (10 lygtis), atspindinčios difuzijos procesų kinetiką $\mathrm{M}_{23} \mathrm{C}_{6}$ karbide ir susijusios su vykstančiais pokyčiais visoje plieno matricoje, išvestas šio proceso trukmès ir temperatūros priklausomumas:

$$
\ln t_{2}=\ln t_{1}-\mathrm{C}\left(1000 / T_{1}-1000 / T_{2}\right)
$$

čia: $\mathrm{C}=E / R$ - plieno konstanta (P91 ir 12X1M $\Phi$ C reikšmé atitinkamai lygi $-29,8$ ir $-17,1)$; $t_{2}$ - apskaičiuotas ekvivalentinis sendinimo laikas temperatūroje $T_{2} ; t_{1}, T_{1}$ - sendinimo laikas ir temperatūra.

Apibendrinta JMA lygties galiojimo sritis P91 plienui pateikta 13 pav.

Ribotos JMA lygties galiojimo trukmès priežastis yra ta, kad termiškai sendinant $\mathrm{P} 91$ plieną chromo kiekis $\mathrm{M}_{23} \mathrm{C}_{6}$ karbide palaipsniui artejja prie prisotinimo ribos, taip pat lèteja ir kristalinès gardelès $a$ parametro kitimas, tačiau didžiausia nustatyta $a$ vertè nepasiekia gardelès, kurioje visa geležis yra pakeista chromu, t. y. $\mathrm{Cr}_{23} \mathrm{C}_{6}$ (1,06599 nm PDF No 35-783 [28]), dydžio [40].

12X1MФ plienui JMA lygtis galioja visą sendinimo / eksploatavimo laikotarpi (žr. 10 pav.), nes chromo kiekis šio plieno $\mathrm{M}_{23} \mathrm{C}_{6}$ karbide, remiantis gautais tyrimo duomenimis, nepasiekia prisotinimo ribos.

\section{IŠVADOS}

Atlikti karštyje stiprių 12X1MФ ir P91 plienų, sendintų 600, 650 ir $700{ }^{\circ} \mathrm{C}$ temperatūroje, tyrimai parode XRD analizès galimybes kokybiškai ir kiekybiškai ištirti karbidų sudèti, apskaičiuoti atskirų, plieno sudètyje esančių, intermetalinių junginių kristalografinių parametrų vertes bei nustatyti plieno struktūrinių pokyčių dèsningumus, priklausančius nuo temperatūros ir laiko. 
Tiriant senëjimo metu plieną sudarančių intermetalinių junginių struktūrinius pokyčius nustatyta, kad $\mathrm{M}_{23} \mathrm{C}_{6}$ karbidas išlieka ilgą laikotarpi, o jo kristalinès gardelès parametro $a$ vertė vykstant difuziniams procesams kinta dèsningai, todèl šių procesų kinetika gali būti taikoma kaip trukmès ir temperatūros indikatorius plieno senéjimo poveikiui įvertinti.

Nustatyta, kad tirtujų plienų $\mathrm{M}_{23} \mathrm{C}_{6}$ karbido kristalinès gardelès $a$ parametro pokyčio kinetiką senèjimo metu galima aprašyti Johnson-Mehl-Avrami dèsniu. Apskaičiuotos $\mathrm{M}_{23} \mathrm{C}_{6}$ karbido gardelès transformacijos aktyvacijos energijos: $12 \mathrm{X} 1 \mathrm{M} \Phi$ plienui $E=142 \mathrm{~kJ} / \mathrm{mol}$, o P91 plienui $E=248 \mathrm{~kJ} / \mathrm{mol}$.

Iš gautų išraiškų, apibūdinančių $\mathrm{M}_{23} \mathrm{C}_{6}$ karbido gardelès $a$ parametro pokyčio, kuris yra susijęs su difuzijos procesais, vykstančiais visoje plieno matricoje, kinetiką, gauta lygtis, apibrèžianti ši pokyti trukmès ir temperatūros priklausomumu. Nustatytos parametro $a$ vertès prognozavimo kinetinių lygčių galiojimo sąlygos P91 plienui. 12X1MФ plieno atveju nustatyta, kad gardelès $a$ parametro pokyčio kinetiniai dèsningumai, skirtingai nei pliene P91, nesikeičia, todèl prognozavimo lygtis galioja visą plieno eksploatavimo laikotarpị.

\section{PADE்KA}

Tyrimus finansavo Lietuvos mokslo taryba (sutarties Nr. MIP-023/2014).

Gauta 20160627 Priimta 20160804

\section{Literatūra}

1. Thomson R. C. Carbide Composition Changes in Power Plant Steels as a Method of Remnant Creep Life Prediction. Doctor Thesis. Cambridge, England, 1992. $226 \mathrm{p}$.

2. Masuyama F. History of power plants and progress in heat resistant steels. ISIJ International. 2001. Vol. 41. No. 6. P. 612-625.

3. Mitchell D. R. G., Ball C. J. A. Quantitative X-ray diffraction and analytical electron microscopy study of service-exposed 2.25Cr-1Mo steels. Materials Characterization. 2001. Vol. 47. P. 17-26.

4. Rudzinskas V., Valiulis A. V., Černašèjus O., Višniakov N. Dynamics of properties and struc- ture changes of pearlite steel during long-lived operation. Materials Science- Medžiagotyra. 2003. Vol. 9. No. 2. P. 164-168.

5. Antikayn P. A. Metally $i$ raschyot na prochnost' $i$ trubopovodov. Moskva: Energoatomizdat, 1990. $368 \mathrm{s.}$

6. Gustafson A., Hattestrand M. Coarsening of precipitates in an advanced creep resistant chromium steel - quantitative microscopy and simulations. Materials Science and Engineering. 2002. A333. P. 279-286.

7. Race J. M., Bhadeshia H. K. D. H. Precipitation sequences during carburisation of Cr-Mo steel. Materials Science and Technology. October 1992. Vol. 8. P. 875-882.

8. Li H., Mitchell D. Microstructural characterization of P91 steel in the virgin, service exposed and post-service re-normalized conditions. Steel Research International. 2013. Vol. 84. Iss. 12. P. 1302-1308.

9. Tulyakov G. A. Termicheskaya ustalost'v teploenergetike. Moskva: Mashinostroenie, 1976. 199 s.

10. Zhao J., Han S., Gao H., Wang L. Remaining life assessment of a $\mathrm{CrMoV}$ steel using the Z-parameter method. International Journal of Pressure Vessels and Piping. 2004. Vol. 81. P. 757-760.

11. Das C. R., Albert S. K., Bhaduri A. K., Srinivasan G., Murty B. S. Effect of prior microstructure on microstructure and mechanical properties of modified 9Cr-1Mo steel weld joints. Materials Science and Engineering. 2008. Vol. 477 A. P. 185-192.

12. Dobrzanski J. Internal damage processes in low alloy chromium-molybdenum steels during high-temperature creep service. Journal of $\mathrm{Ma}$ terials Processing Technology. 2004. Vol. 157/158. P. 297-303.

13. Zielinski A., Dobrzanski J., Krzton H. Structural changes in low alloy cast steel Cr-Mo-V after long time creep service. Journal of Achievements in Materials and Manufacturing Engineering. 2007. Vol. 25. No. 1. P. 33-36.

14. Mandziej S. T. Accelerated microstructure transformation caused by thermal-mechanical fatique. Materials Science Forum. 2012. Vol. 706709. P. 871-877.

15. Tezuka H., Sakurai T. A trigger of Type IV damage and a new heat treatment procedure to suppress it. Microstructural investigations of 
long-term ex-service Cr-Mo steel pipe elbows. International Journal of Pressure Vessels and Piping. 2005. Vol. 82. P. 165-174.

16. Spigarelli S. Microstructure-based assessment of creep rupture strength in 9Cr steels. International Journal of Pressure Vessels and Piping. 2013. Vol. 101. P. 64-71.

17. Vodarek V., Strang A. Minor-phase composition changes in $12 \mathrm{CrMoVNb}$ steels during long-term exposure. Materials Chemistry and Physics. 2003. Vol. 81. P. 480-482.

18. Sanchez-Hanton J. J., Thomson R. C. Characterization of isothermally aged Grade $91(9 \mathrm{Cr}-$ $1 \mathrm{Mo}-\mathrm{Nb}-\mathrm{V})$ steel by electron backscatter diffraction. Materials Science and Engineering A. 2007. Vol. 460/461. P. 261-267.

19. Fujita N. Modelling Carbide Precipitation in Alloy Steels. Doctor Thesis. Cambridge, England, 2000. $216 \mathrm{p}$.

20. Janovec J., Svoboda M., Vyrostkova A., Kroupa A. Time-temperature-precipitation diagrams of carbide evolution in low alloy steels. Materials Science and Engineering. 2005. Vol. 402A. P. 288-293.

21. Robson J. D., Bhadeshia H. K. D. H. Kinetics of precipitation in power plant steels. CALPHAD. 1996. Vol. 20. No. 4. P. 447-460.

22. Lanskaya K. A., Kulikova L. V., Veksler E. Ya., Chaykovskii V. M. Struktura i svoystva dlitel'no rabotayushchikh tub iz stali 12X1MФ. Teploenergetika. 1975. Nr. 10. S. 9-10.

23. Parida P. K., Dasgupta A., Saibaba S. Study of microstructure and microtexture of modified $9 \mathrm{Cr}$ 1 Mo steel subjected to high deformation. Journal of Nuclear Materials. 2013. Vol. 432(1-3). P. 450-454.

24. Panait C. G., Bendick W., Fuchsmann A., Gourgues-Lorenzon A. F, Besson J. Study of the microstructure of the grade 91 steel after more than $100,000 \mathrm{~h}$ of creep exposure at $600{ }^{\circ} \mathrm{C}$. International Journal of Pressure Vessels and Piping. 2010. Vol. 87(6). P. 326-335.

25. Srinivas Prasad B. S., Rajkumar V. B., Hari Kumar K. C. Numerical simulation of precipitate evolution in ferritic-martensitic power plant steels. CALPHAD. 2012. Vol. 36. P. 1-7.

26. Korcakova L., Hald J., Somers M. A. J. Quantification of laves phase particle size in $9 \mathrm{CrW}$ steel. Materials Characterization. 2001. Vol. 47(2). P. 111-117.
27. https://www.bruker.com/products/x-ray-diffraction-and-elemental-analysis/x-ray-diffraction/xrd-software/overview/eva.html/ [žiūrèta 2015-01-03].

28. Joint Committee on Powder Diffraction Standards (JCPDS) - International centre for diffraction data (ICDD), Powder Diffraction File (PDF)-2 database. Philadelphia, USA, 2003.

29. TOPAS V4: General profile and structure analysis software for powder diffraction data. - User's Manual, Bruker AXS, Karlsruhe, Germany. http://www.topas-academic.net/ [žiūrèta 201501-03].

30. Baltušnikas A., Lukošiūtė I., Levinskas R. Transformation kinetics of $\mathrm{M}_{23} \mathrm{C}_{6}$ carbide lattice parameters in low alloyed steel. Materials ScienceMedžiagotyra. 2010. Vol. 16. No. 4. P. 320-323.

31. Christian J. W. The Theory of Transformation in Metals and Alloys, 2nd ed. Pergamon-Press, 1975. $586 \mathrm{p}$.

32. Galwey A., Brown M. Application of the Arrhenius equation to solid state kinetics: can this be justified? Thermochimica Acta. 2002. Vol. 386. No. 1. P. 91-98.

33. Vittayakorn N. Phase formation and crystal structure of $0.9 \mathrm{PZT}-0.1 \mathrm{PZN}$ powders prepared by columbite precursor. Journal of Applied Science Research. 2006. Vol. 2. No. 12. P. 1355-1358.

34. Adamaszek K., Jurasz Z. Comparison of two methods of calculation of activation energy for some chosen industrial steels after its oxidation at high-temperatures in air. Defect and Diffusion Forum. 2005. Vol. 237/240. P. 979-984.

35. Heireche L., Belhadji M. The methods Matusita, Kissinger and Ozawa in the study of the crystallization of glasses. The case of $\mathrm{Ge}-\mathrm{Sb}$-Te alloys. Chalcogenide Letters. 2007. Vol. 4. No. 2. P. 23-33.

36. Levinskas R., Baltušnikas A., Lukošiūtė I., Kriūkienè R. Optical and XRD study of microstructure alteration during ageing of steel. Proceedings of V International Scientific Conference BALTRIB'2009, Kaunas, Lithuanian University of Agriculture, November 19-21, 2009, Kaunas. P. 170-175.

37. Levinskas R., Baltušnikas A., Lukošiūtè I. Perlitinio karščiui atsparaus plieno 12X1MF karbidinès fazès elektrocheminio atskyrimo parametrų nustatymas. Energetika. 2007. Nr. 3. P. 77-83. 
38. Levinskas R., Baltušnikas A., Lukošiūtè I., Grybėnas A., Kriūkienè R. Some aspects of XRD investigation of heat resistant steel structure degradation by thermal ageing. Proceedings of the 14th International Conference Mechanika 2009, April 2-3, 2009, Kaunas University of Technology, Kaunas, Lithuania. P. 239-243.

39. Baltušnikas A., Levinskas R., Lukošiūtė I. Kinetics of carbide formation during ageing of pearlitic 12X1MФ steel. Materials Science-Medžiagotyra. 2007. Vol. 13. No. 4. P. 286-292.

40. Baltušnikas A., Lukošiūtè I., Makarevičius V., Kriūkienė R., Grybėnas A. Influence of thermal exposure on structural changes of $\mathrm{M}_{23} \mathrm{C}_{6}$ carbide in P91. Journal of Materials Engineering and Performance. 2016. Vol. 25. No. 5. P. 1945-1951.

41. Naujos kartos plieno ilgaamžiškumo ìvertinimo modelis: ataskaita. Sutartis Nr. MIP-023/2014, 2015. $27 \mathrm{p}$.

42. Levinskas R., Baltušnikas A., Lukošiūtė I. Assessment of state of power plant steel 12X1M $\Phi$ from the structure point of view. Proceedings of the 13th International Conference Mechanika 2008, April 3-4, 2008, Kaunas University of Technology, Kaunas, Lithuania. P. 314-319.

43. Vodarek V. and Strang A. Compositional Changes in Minor Phases Present in $12 \mathrm{CrMoVNb}$ Steels During Thermal Exposure at $550{ }^{\circ} \mathrm{C}$ and $600{ }^{\circ} \mathrm{C}$. Materials Science and Technology. 2000. Vol. 16. Iss. 10. P. 1207-1213.

44. Baltušnikas A., Levinskas R., Lukošiūtė I. Analysis of heat resistant steel state by changes of lattices parameters of carbides phases. Materials Science-Medžiagotyra. 2008. Vol. 14. No. 3. P. 210-214.

45. Panait C. G., Zielinska-Lipiec A., Koziel T., Czyrska-Filemonowicz A., Gourgues-Lorenzon A. F., Bendick W. Evolution of dislocation density, size of subgrains and MX-type precipitates in a P91 steel during creep and during thermal ageing at $600{ }^{\circ} \mathrm{C}$ for more than 100,000 h. Materials Science and Engineering A. 2010. Vol. 527. No. 1617. P. 4062-4069.

46. Nitta H., Yamamoto T., Kanno R., Takasawa K., Iida T., Yamazaki Y., Ogu S., Iijima Y. Diffusion of molybdenum in a-iron. Acta Materialia. 2002. Vol. 50. P. 4117-4125.
Arūnas Baltušnikas, Irena Lukošiūtè,

Vidas Makarevičius, Rita Kriūkienė,

Rimantas Levinskas, Albertas Grybėnas

ASSESSMENT OF AGEING OF HEAT

RESISTANT STEEL FROM THE STRUCTURAL POINT OF VIEW

\section{Summary}

The microstructure of heat resistant steels grade 12X1MФ and P91 undergoes evolution in the thermal power plant facilities during long-term operation or when tempering in laboratory conditions at 600, 650 , and $700{ }^{\circ} \mathrm{C}$. Structural changes were investigated by XRD analysis, optical and scanning electron microscopy. It was established that the evolutionary sequence of carbides in steel aged at elevated temperatures is the same as that in operated steel. To raise the quantitative content of carbide phases, an optimal electrochemical separation technique was created by analysing the anodic polarization process in different electrolyte solutions. Steel microstructure after thermal treatment was evaluated by changes of integral intensities of $\mathrm{X}$-ray diffraction peaks for $\mathrm{Fe}_{3} \mathrm{C}$ and $\mathrm{M}_{23} \mathrm{C}_{6}$ carbides. Testing revealed that carbide $\mathrm{M}_{23} \mathrm{C}_{6}$ crystal lattice parameter changes as a function of service time and heat exposure in laboratory conditions. Lattice parameter progressively increases due to enhanced diffusion of alloying elements from the matrix into the carbide lattice. Kinetic parameters of $\mathrm{M}_{23} \mathrm{C}_{6}$ lattice transformation were described using the Johnson-Mehl-Avrami (JMA) equation. The activation energy $E$, rate constant $k$ and Avrami exponent $n$ were established, which made it possible to develop a time-temperature relationship for carbide structural parameter transformation in steels. The obtained relationship could be used as an indicator for the assessment of the real temperature exposure time of heat resistant steel.

Keywords: heat resistant steels, ageing, carbides, XRD, JMA equation 